Community and the Creation of Provincial Identities: a re-interpretation of the Romano-British aisled building at North Warnborough

Lacey M. Wallace

Pages 1-24 | Published online: 06 Nov 2017

https://doi.org/10.1080/00665983.2017.1389148

Abstract

The aisled hall at North Warnborough has attracted attention as one of a handful of examples frequently included in surveys and analyses of this common architectural type as well as for arguments related to the gendered use of space. This article presents a new architectural analysis of this building and attempts to set it within its immediate and wider archaeological and geological landscape context. A theoretically informed interpretation of the social significance of this site is offered, which has broader implications for the studies of Romano-British architecture, rural settlement, and landscape.

\title{
INTRODUCTION
}

Aisled halls are characteristic of Romano-British vernacular architecture (they are present on c. 27\% of known 'villa' sites, Smith 2016 Smith, A. 2016. Buildings in the countryside, in A. Smith, M. Allen, T. Brindle, and M. Fulford, The Rural Settlement of Roman Britain, 44-74, London: Society for the Promotion of Roman Studies, Britannia Monogr. Ser., 29, 45, 67) and, because they are not common on continental rural settlement sites or British Late pre-Roman Iron Age (LPRIA) sites, their function, social significance, and origins have been widely debated (Cunliffe 2008a Cunliffe, B. 2008a. The vernacular architecture of the region in the Roman period, in B. Cunliffe (ed.) The Danebury Environs Roman Programme: A Wessex Landscape During the Roman Era, Volume 1, Overview, 113-125, Oxford: English Heritage and Oxford University Comm. for Archaeol. Monogr., 49; 2008b; Hadman 1978 Hadman, J. 1978. Aisled buildings in Roman Britain, in M. Todd (ed.) Studies in Romano-British Villas, 187-195, Leicester: Leicester University Press; Hingley 1989 Hingley, R. 1989. Rural Settlement in Roman Britain, London: Seaby; Richmond 1969 Richmond, I.R. 1969. The plans of Roman villas in Britain, in A.L.F. Rivet (ed.) The Roman Villa in Britain, 49-70, London: Routledge; Smith 1963 Smith, J.T. 1963. Romano-British aisled houses, Archaeol. J., 120, 1-30; 1978a Smith, J.T. 1978a. Hall or yards? A problem of villa interpretation, Britannia, 9, 351-358; and 1997 Smith, J.T. 1997. Roman Villas: A Study in Social Structure, London: Routledge; Taylor 2011 Taylor, J. 2011. The Idea of the Villa. Reassessing Villa Development in South-East Britain in N. Royman and T. Derks (eds) Villa Landscapes in the Roman North: Economy, Culture, and Lifestyles, 179-194, Amsterdam, Amsterdam University Press; 2013 Taylor, J. 2013. Encountering romanitas: characterising the role of agricultural communities in Roman Britain, Britannia 44, 171-490). They may have shared similar architectural origins with those in urban contexts (more usually referred to as 'basilicas') or with a handful of aisled halls on rural sites in Ireland (Richmond 1932 Richmond, I.A. 1932. Irish analogies for the Romano-British barn dwelling, J. of Roman Stud., 22, 96-106), Germany (Smith 1963 Smith, J.T. 1963. Romano-British aisled houses, Archaeol. J., 120, 1-30; 1997 Smith, J.T. 1997. Roman Villas: A Study in Social Structure, London: Routledge, 221), and Gaul (Todd 1992 Todd, M. 1992. Aisled 
halls in Roman Gaul, Oxford J. of Archaeol., 11(3), 369-372), but Cunliffe (2008a Cunliffe, B. 2008 a. The vernacular architecture of the region in the Roman period, in B. Cunliffe (ed.) The Danebury Environs Roman Programme: A Wessex Landscape During the Roman Era, Volume 1, Overview, 113125, Oxford: English Heritage and Oxford University Comm. for Archaeol. Monogr., 49) has argued this architectural form was required to fulfil both continuing and new values, activities, and traditions in new structural contexts. Recent explorations of the symbolic and community functions of aisled halls (Cunliffe 2008a Cunliffe, B. 2008a. The vernacular architecture of the region in the Roman period, in B. Cunliffe (ed.) The Danebury Environs Roman Programme: A Wessex Landscape During the Roman Era, Volume 1, Overview, 113-125, Oxford: English Heritage and Oxford University Comm. for Archaeol. Monogr., 49; 2008b Cunliffe, B. 2008b. Some thoughts on aisled halls, in B. Cunliffe (ed.) The Danebury Environs Roman Programme: A Wessex Landscape During the Roman Era, Volume 1, Overview, 126-129, Oxford: English Heritage and Oxford University Comm. for Archaeol. Monogr., 49; and 2013a Cunliffe, B. 2013a. 'For men of rank...basilicas': british aisled halls reconsidered, in H. Eckhardt and S. Rippon (eds) Living and Working in the Roman World, 95109, Portsmouth, RI: Journal of Roman Archaeology Suppl. Ser. 95; Taylor 2011 Taylor, J. 2011. The Idea of the Villa. Reassessing Villa Development in South-East Britain in N. Royman and T. Derks (eds) Villa Landscapes in the Roman North: Economy, Culture, and Lifestyles, 179-194, Amsterdam, Amsterdam University Press) have inspired this reassessment of an often-cited, but littleunderstood, aisled hall at Lodge Farm, North Warnborough, Odiham, Hants. (Illus. 1; Liddell 1929 Liddell, D.M. 1929. Report on the Excavation of a Roman Building at Lodge Farm, North Warnborough, Hants., Hampshire County Museums Headquarters Archives, unpublished manuscript; 1931 Liddell, D.M. 1931. Notes on two excavations in Hampshire, Proc. of the Hampshire Field Club and Archaeol. Soc., 10, 224-236; Collingwood and Taylor 1931 Collingwood, R. and Taylor, M.V. 1931. Roman Britain in 1930, J. of Roman Stud., 21, 215-250).

Illus. 1. Location of the site at Lodge Farm, North Warnborough in relation to Calleva Atrebatum (Silchester) and known Roman-period roads and settlements (including data from Allen et al. 2015 Allen, M., Blick, N., Brindle, T. Evans, T., Fulford, M., Holbrook, N., Richards, J.D., and Smith, A. 2015 (updated 2016). The Rural Settlement of Roman Britain: an online resource, Archaeology Data Service,

http://archaeologydataservice.ac.uk/archives/view/romangl/ and the Portable Antiquities Scheme, 15 August 2017). Scale 1:100,000. (Topographic and geological data: Crown copyright/database right 2016. An Ordnance Survey/EDINA supplied service.)

Like many other aisled buildings (e.g. Carisbrooke, Brading, and Stroud), the example at North Warnborough was originally a vast open internal space and developed in structural phases. Examining the 'trajectory of development' (Cunliffe 2008a Cunliffe, B. 2008a. The vernacular architecture of the region in the Roman period, in B. Cunliffe (ed.) The Danebury Environs Roman Programme: A Wessex Landscape During the Roman Era, Volume 1, Overview, 113-125, Oxford: English Heritage and Oxford University Comm. for Archaeol. Monogr., 49), which is often overlooked, can provide significant information for interpretations of function and significance. The variety of scale across the known examples (c. 50-800 m2, Smith 2016 Smith, A. 2016. Buildings in the countryside, in A. Smith, M. Allen, T. Brindle, and M. Fulford, The Rural Settlement of Roman Britain, 44-74, London: Society for the Promotion of Roman Studies, Britannia Monogr. Ser., 29, 67) demonstrates that the heights and internal areas of aisled buildings may be partly indicative of their 
functions and the status they communicated (Cunliffe 2013a Cunliffe, B. 2013a. 'For men of rank...basilicas': british aisled halls reconsidered, in H. Eckhardt and S. Rippon (eds) Living and Working in the Roman World, 95-109, Portsmouth, RI: Journal of Roman Archaeology Suppl. Ser. 95, 98). An examination of the impact of this relatively large example (c. $484 \mathrm{~m} 2$ ) using viewshed analysis and taking account of its surrounding architectural and landscape context could illuminate its possible function, connection to social networks, and the meaning it communicated across the landscape. Later-phase alterations-which have formed the basis for all previous discussions of this building-must be separated from the original design and social significance.

North Warnborough has received a great deal of attention in the literature, largely stemming from Hingley's (1989 Hingley, R. 1989. Rural Settlement in Roman Britain, London: Seaby, 43-45) discussion of kin-group habitation and gendered space (derived from Liddell 1931 Liddell, D.M. 1931. Notes on two excavations in Hampshire, Proc. of the Hampshire Field Club and Archaeol. Soc., 10, 224-236, 235-236 and repeated by Applebaum 1972 Applebaum, S. 1972. Roman Britain, in H.P.R. Finberg (ed.) The Agrarian History of England and Wales I:II (AD 43-1042), 3-270, Cambridge: Cambridge University Press, 16-18 and Black 1987 Black, E.W. 1987. The Roman Villas of South-East England, Oxford: Brit. Archaeol. Rep. Brit. Ser., 171, 79). In analysing the internal divisions, others have suggested division by status like a manorial hall and combinations of human and animal habitation ('barn-dwellings') with comparison to Frisian examples. Critiques of these discussions related to North Warnborough have been offered (e.g. Perring 2002 Perring, D. 2002. The Roman House in Britain, London: Routledge, 11-12, 209; Rogers 2015 Rogers, A. 2015. The Archaeology of Roman Britain: Biography and Identity, New York: Routledge, 110; Smith 1997 Smith, J.T. 1997. Roman Villas: A Study in Social Structure, London: Routledge, 37; Smith 2016 Smith, A. 2016. Buildings in the countryside, in A. Smith, M. Allen, T. Brindle, and M. Fulford, The Rural Settlement of Roman Britain, 44-74, London: Society for the Promotion of Roman Studies, Britannia Monogr. Ser., $29,55)$, but without analysis of the archaeology, such as the evidence allows.

The current understanding of the site's phasing and archaeological evidence is less than ideal and the records of the excavation are incomplete, as might be expected for a site excavated in 1929-31. A re-examination of the evidence is, nonetheless, a fruitful way to explore the hypotheses. Such an assessment is offered below, followed by a more nuanced and contextual understanding of the role of this structural complex in the rural landscape.

\section{STRUCTURAL CONTEXT AND PHASING}

Two buildings were excavated at North Warnborough, here referred to as Buildings 1 and 2 (Illus. 2). Although the excavation was not strictly stratigraphic, certain observations (Liddell 1929 Liddell, D.M. 1929. Report on the Excavation of a Roman Building at Lodge Farm, North Warnborough, Hants., Hampshire County Museums Headquarters Archives, unpublished manuscript and 1931 Liddell, D.M. 1931. Notes on two excavations in Hampshire, Proc. of the Hampshire Field Club and Archaeol. Soc., 10, 224-236) allow a possible phasing structure to be suggested (Illus. 3-Illus. 8), but, given the original conditions of the excavation, it cannot be considered definitive. 
Illus. 2. Multi-phase plan (after Liddell 1931 Liddell, D.M. 1931. Notes on two excavations in Hampshire, Proc. of the Hampshire Field Club and Archaeol. Soc., 10, 224-236, plate IV and Collingwood and Taylor 1931 Collingwood, R. and Taylor, M.V. 1931. Roman Britain in 1930, J. of Roman Stud., 21, 215-250, 243, fig. 24).

Illus. 3. Phase 1a (after Liddell 1931 Liddell, D.M. 1931. Notes on two excavations in Hampshire, Proc. of the Hampshire Field Club and Archaeol. Soc., 10, 224-236, plate IV and Collingwood and Taylor 1931 Collingwood, R. and Taylor, M.V. 1931. Roman Britain in 1930, J. of Roman Stud., 21, 215-250, 243, fig. 24). Positions of Building 2 aisle posts estimated from the northeasternmost extant posthole shown here. (NB: Hypocaust $\mathrm{K}$ and the wall between Rooms $\mathrm{M}$ and $\mathrm{N}$ were proposed as primary by Liddell (1931 Liddell, D.M. 1931. Notes on two excavations in Hampshire, Proc. of the Hampshire Field Club and Archaeol. Soc., 10, 224-236), but may belong to Phase $1 \mathrm{~b}$ (Illus. 4).) It is likely that the floors of Building 2 were either of chalk (as the hypocaust, $\mathrm{K}$ ) or stamped earth. Scarlet and blue wall plaster found beneath later floor levels in the hall indicates decoration likely to belong to this phase.

Illus. 4. Phase 1b (after Liddell 1931 Liddell, D.M. 1931. Notes on two excavations in Hampshire, Proc. of the Hampshire Field Club and Archaeol. Soc., 10, 224-236, plate IV and Collingwood and Taylor 1931 Collingwood, R. and Taylor, M.V. 1931. Roman Britain in 1930, J. of Roman Stud., 21, 215-250, 243, fig. 24).

Illus. 5. Phase 2a (after Liddell 1931 Liddell, D.M. 1931. Notes on two excavations in Hampshire, Proc. of the Hampshire Field Club and Archaeol. Soc., 10, 224-236, plate IV and Collingwood and Taylor 1931 Collingwood, R. and Taylor, M.V. 1931. Roman Britain in 1930, J. of Roman Stud., 21, 215-250, 243, fig. 24). The wall separating Building 1 Rooms D and F was partially constructed across the open pit. The walls of Room B were replastered in pink.

Illus. 6. Phase 2b (after Liddell 1931 Liddell, D.M. 1931. Notes on two excavations in Hampshire, Proc. of the Hampshire Field Club and Archaeol. Soc., 10, 224-236, plate IV and Collingwood and Taylor 1931 Collingwood, R. and Taylor, M.V. 1931. Roman Britain in 1930, J. of Roman Stud., 21, 215-250, 243, fig. 24). Building 1 Room D had white wall plaster with bands of black and red and a floral scroll design in red, brown, yellow, and black (Illus. 7), and Room F had dark rose-coloured plaster walls.

Illus. 7. Watercolour painting of plaster fragments from Building 1 Room D (Liddell 1929 Liddell, D.M. 1929. Report on the Excavation of a Roman Building at Lodge Farm, North Warnborough, Hants., Hampshire County Museums Headquarters Archives, unpublished manuscript).

Illus. 8. Phase 3 (after Liddell 1931 Liddell, D.M. 1931. Notes on two excavations in Hampshire, Proc. of the Hampshire Field Club and Archaeol. Soc., 10, 224-236, plate IV and Collingwood and Taylor 1931 Collingwood, R. and Taylor, M.V. 1931. Roman Britain in 1930, J. of Roman Stud., 21, 215-250, 243 , fig. 24). Building 2 Room $K$ had plastered walls in white with a narrow red line and $O$ had dark rose-coloured walls; it is likely that these plaster fragments relate to this latest phase. Building 2 
Room $S$ contained a large quantity of wood ash, burning, as well as food remains, including oyster shells; Q contained a large midden of pottery, animal bones, and oyster shells; Room W contained a hearth. Postholes in the centre of the nave may be remains of supports for sagging roof beams towards the end of the life of the building-their locations are consistent with the aisle post reconstruction suggested in the illustrations here.

Both buildings have earlier well-built flint or flint-and-tile walls (Phase 1a, Illus. 3): Building 1 was originally a cottage-style dwelling and Building 2 was constructed as a simple aisled hall (following definitions in Cunliffe 2008a Cunliffe, B. 2008a. The vernacular architecture of the region in the Roman period, in B. Cunliffe (ed.) The Danebury Environs Roman Programme: A Wessex Landscape During the Roman Era, Volume 1, Overview, 113-125, Oxford: English Heritage and Oxford University Comm. for Archaeol. Monogr., 49, 113-114) of grand proportions. The width of the building (c. $16.7 \mathrm{~m}$ ) appears to be greater than any other known British aisled hall except for Brading, Isle of Wight, Hants. (Cunliffe 2013a Cunliffe, B. 2013a. 'For men of rank...basilicas': british aisled halls reconsidered, in H. Eckhardt and S. Rippon (eds) Living and Working in the Roman World, 95-109, Portsmouth, RI: Journal of Roman Archaeology Suppl. Ser. 95), which is significant because it corresponds to the possible grand height of the structure, especially if a raised clerestory roof was created (as is known from the remains of the aisled hall façade at Meonstoke, Hants., King and Potter 1990 King, A.C. and Potter, T.W. 1990. A new domestic building-facade from Roman Britain, J. of Roman Archaeol., 3, 195-204).

After the simple aisled building was constructed, a strip of rooms was added at one exterior end and corner pavilions connected by small entrance rooms at the other (Phase $1 \mathrm{~b}$, Illus. 4). The range on the southwestern side can be compared to strip houses (see Cunliffe 2008a Cunliffe, B. 2008a. The vernacular architecture of the region in the Roman period, in B. Cunliffe (ed.) The Danebury Environs Roman Programme: A Wessex Landscape During the Roman Era, Volume 1, Overview, 113-125, Oxford: English Heritage and Oxford University Comm. for Archaeol. Monogr., 49, 121), while the corner pavilions reflect a wider tradition of elaboration that aisled halls shared in common with 'winged corridor' buildings. The symmetry evident in Building 2's gable-end ranges indicates that the façade was the northeastern corner pavilion end, which lay at a right angle to (and was connected by a short wall to) the smaller Building 1 . This layout, along with one short wall on the side opposite to Building 1, suggests a courtyard arrangement; extensions of the complex have also been identified through surface observation (Liddell 1929 Liddell, D.M. 1929. Report on the Excavation of a Roman Building at Lodge Farm, North Warnborough, Hants., Hampshire County Museums Headquarters Archives, unpublished manuscript, 1931 Liddell, D.M. 1931. Notes on two excavations in Hampshire, Proc. of the Hampshire Field Club and Archaeol. Soc., 10, 224-236) and field-walking (Hughes 1981 Hughes, M. (ed.). 1981: Archaeology in Hampshire, Annual Report for 1980, Hampshire County Planning Department, Hampshire County Council and 1982 Hughes, M. (ed.). 1982: Archaeology in Hampshire, Annual Report for 1981, Hampshire County Planning Department, Hampshire County Council). Previous assertions that Building 2 resembled a winged corridor building, with an entrance on the long side (e.g. Cunliffe 2008a Cunliffe, B. 2008a. The vernacular architecture of the region in the Roman period, in B. Cunliffe (ed.) The Danebury Environs Roman Programme: A Wessex Landscape During the Roman Era, Volume 1, Overview, 113-125, Oxford: English Heritage and Oxford University Comm. for Archaeol. Monogr., 49, 117; Cunliffe 2013a Cunliffe, B. 2013a. 'For men of rank...basilicas': british aisled halls reconsidered, in H. Eckhardt and S. Rippon (eds) Living and Working in the Roman World, 95-109, Portsmouth, RI: Journal of Roman Archaeology Suppl. Ser. 95, 
fig. 6.2; Smith 1963 Smith, J.T. 1963. Romano-British aisled houses, Archaeol. J., 120, 1-30, 5,7 and 1978b Smith, J.T. 1978b. Villas as a key to social structure, in M. Todd (ed.) Studies in the RomanoBritish Villa, 149-185, Leicester: Leicester University Press, 150), likely derive from the use of an incomplete plan (Liddell 1931 Liddell, D.M. 1931. Notes on two excavations in Hampshire, Proc. of the Hampshire Field Club and Archaeol. Soc., 10, 224-236, plate II instead of Collingwood and Taylor 1931 Collingwood, R. and Taylor, M.V. 1931. Roman Britain in 1930, J. of Roman Stud., 21, 215-250, 243, fig. 24). Both buildings were then modified with 'poorly built' flint walls of smaller dimensions (Phase 2, Illus. 5 and Illus. 6); Building 1 was converted to a bath building (Phase 2b), later reduced in size (Phase 3, Illus. 8), and the aisled hall was internally divided with wattle-and-plaster walls and gained hearths and internal middens, likely indicating habitation/food-preparation areas (Phase 3).

Features of the buildings that cannot be assigned a suggested phase include the roofing materials (ceramic tiles and purbeck 'slates'), the plastering of one outer wall of Building 1, window glass, and the floors of unmodified rooms with only one floor level (Rooms H, J, L3, L4). Mentions of wall plaster in Rooms $\mathrm{K}$ and $\mathrm{O}$ do not specify the relationship to the floor levels, but elsewhere it is made clear. The figures (Illus. 3-Illus. 8) provide sufficient description of the evidence and proposed phasing; gratuitous description is avoided here and below are notes to accompany the illustrations and explain this interpretation of the development of the complex.

Phase 1a

Building 1, house

No entrance is apparent, but the placement of the later furnace/flu at the northwestern side of Room B, along with the probable 'courtyard' arrangement of Phase $1 \mathrm{~b}$ (Illus. 4), suggests it was perhaps on the southeastern side. A large (1.8 m x $1.5 \mathrm{~m}$ in diameter, $0.9 \mathrm{~m}$ deep) clay-and-flintlined pit in the middle of Room D/F is of uncertain function, but likely for under-floor storage.

Building 2, aisled hall

Liddell (1931 Liddell, D.M. 1931. Notes on two excavations in Hampshire, Proc. of the Hampshire Field Club and Archaeol. Soc., 10, 224-236) determined that the earliest phase of the aisled hall consisted of walls as shown, based on the apparently integral nature of the hypocaust $(K)$ and outer walls and their similarity, but the hypocaust and wall may date to a later phase (Phase $1 \mathrm{~b}$ ), which would be more in keeping with other examples of aisled halls that tend to begin as completely open and are only internally subdivided later. The channeled hypocaust had two openings into the 'nave', suggesting either that hot, smoky air was allowed to circulate around the hall or that a wall containing flue tiles to direct the smoke up to vents/chimneys in the roof had been destroyed. One of the recorded postholes probably represents an aisle support, but the others do not appear to have a consistent alignment; it is most likely that postholes were missed during excavation or destroyed; the width is too great to be spanned by a single roof beam and painted wall plaster 
indicates the building was not an open yard (cf. Smith 1978a Smith, J.T. 1978a. Hall or yards? A problem of villa interpretation, Britannia, 9, 351-358).

Phase $1 b$

Building 1, house

The northeastern end of Room B was re-shaped into an apse, refloored and the walls replastered, perhaps an enhancement of a reception room. The late Roman-period trend of adding or converting rooms to apsidal spaces is well documented from the late third century onwards. The closing off of Room $\mathrm{G}$, along with its more utilitarian floor, suggests it may have been given a more private function.

Building 2, aisled hall

The construction materials and methods used to build the corner pavilions and rear rooms of the aisled hall appear similar to those of Phase 1a. The pavilions are not symmetrical with the façade, but, rather, are constricted to form a right angle with the corner of Building 1, suggesting both were already standing when the pavilions were constructed (see measurements on Illus. 4). The rear rooms were likely built at the same time.

Phase $2 a$

Building 1, house

A floor of pink plaster was laid in Rooms D and E, suggesting the higher-status, more public nature of these rooms. The character of the wall separating Rooms D and F-'the worst piece of workmanship in the whole building' (Liddell 1929 Liddell, D.M. 1929. Report on the Excavation of a Roman Building at Lodge Farm, North Warnborough, Hants., Hampshire County Museums Headquarters Archives, unpublished manuscript)-indicates that this phase of alterations was undertaken by unskilled labourers with low-quality materials.

Phase $2 b$

Building 1, bathhouse 
Weak walls of composite materials were also used when the house was converted to a bathhouse, which was accomplished through the construction of a furnace (Illus. 6, A), insertion of a hypocaust floor (Room B, later removed, and Room D), construction of a likely plunge bath (Room F), and drains in Rooms $D$ and $G$. Three flint/limestone-and-mortar buttresses along the northeastern exterior wall were probably added at this time (to support the water tubs along the interior of this wall?); the only other use of limestone in this building is in the furnace (A) walls, indicating possible contemporaneity. Room D was the most highly decorated (Illus. 7).

Building 2, aisled hall

Poorly-built flint 'walls' in the aisles ( $\mathrm{M}, \mathrm{N}$, and $\mathrm{V}$ ) began to reduce the space of the hall. The 'walls' of Room $V$ created a long, narrow space, which may indicate that they supported a raised storage area above (i.e. the 'granary' proposed by Applebaum (1972 Applebaum, S. 1972. Roman Britain, in H.P.R. Finberg (ed.) The Agrarian History of England and Wales I:II (AD 43-1042), 3-270, Cambridge: Cambridge University Press) - see below), a slightly raised floor, or other installation. They are unlikely to have created a 'room' as there is only $1.3 \mathrm{~m}$ between them and a space $0.8 \mathrm{~m}$ between the southeastern and the interior of the outer wall. These walls are of a similar nature to the final house phase (Phase 2a) and first bath phase (Phase 2b) walls of Building 1 and so cannot be associated with one or the other.

Phase 3

Building 1, bathhouse

In the final phase, the bath building was reduced in size and a second furnace (C) was constructed within the apsidal Room B, which then became a fuel store and stoke hole, exterior to the bathing rooms-perhaps because the former 'tepidarium' (Room D/E) was not warm enough or the inhabitants could no longer afford the fuel to heat such a large bathhouse.

Building 2, aisled hall

The final structural phase of the aisled hall was the division of the space with wattle-and-plaster walls, visible as 'channels' and preserved charred fragments; the northwestern aisle was too poorly preserved to indicate if it too contained rooms. Hearths and extensive refuse deposits were found within three of these rooms $(S, Q$, and $W)$, indicating a significant change in function and status. 
As the ceramics and other artefacts were not collected stratigraphically and because no contexts underlying the buildings were investigated, it is impossible to determine the construction date of the complex. Final reports of the pottery and coins were never published or archived, but Liddell noted that the materials broadly indicated a third-fourth-century date range. The four coins from Building 1 dated to between AD 260 and 383; 71 coins from Building 2 dated to between 306 and 381, while coins recorded in the immediate vicinity by the Portable Antiquities Scheme date to the second to fourth centuries. The excavation produced a high proportion of coarse wares, with broad date ranges, and only a few examples of fine wares. The nearby tile kiln (see Illus. 1; Graham 1971 Graham, K.D. 1971. The Roman tile kiln at Scotland Farm, near Hook, Hants, J. of the Farnham Museum Soc., 1, 22-29) is dated to after C. AD 330 on the basis of coins and may indicate a significant moment of reconstruction for the vast roof of the aisled hall. The tiles from the two excavations have not, however, been compared.

\section{ASSESSING INTERPRETATIONS}

This evaluation of the evidence and proposed phasing complicates previous readings of the architecture at North Warnborough, which tended to focus on the function and social significance of later internal divisions, not why the aisled hall was originally constructed. Simple, open aisled buildings may have been used in a similar way to LPRIA round houses, their interiors used for communal living/feasting, production, and processing in space not differentiated into separate rooms (Millett 1990 Millett, M. 1990. The Romanization of Britain, Cambridge: Cambridge University Press, 200-201; Cunliffe 2008b Cunliffe, B. 2008b. Some thoughts on aisled halls, in B. Cunliffe (ed.) The Danebury Environs Roman Programme: A Wessex Landscape During the Roman Era, Volume 1, Overview, 126-129, Oxford: English Heritage and Oxford University Comm. for Archaeol. Monogr., 49, 127; 2013a Cunliffe, B. 2013a. 'For men of rank...basilicas': british aisled halls reconsidered, in H. Eckhardt and S. Rippon (eds) Living and Working in the Roman World, 95-109, Portsmouth, RI: Journal of Roman Archaeology Suppl. Ser. 95, 106; Taylor 2001 Taylor, J. 2001. Rural society in Roman Britain, in S. James and M. Millett (eds) Britons and Romans: Advancing an Archaeological Agenda, 46-59, York: Council for British Archaeology, Research Report 125, 51-52). In such a large example as that at North Warnborough, however, heating it would require significantly more energy than even a very large roundhouse-the internal space of a roundhouse $15 \mathrm{~m}$ in diameter would be c. $177 \mathrm{~m} 2$, whereas the area of Building 2 Phase 1a was c. $484 \mathrm{~m} 2$, indicating that comparison of domestic use and (multi)functionality would be unequal. The Phase $1 \mathrm{~b}$ gable-end ranges, which both added to the architectural impact and provided space for smaller-scale activities, did not impinge on the large space provided by the hall itself and, as it was positioned alongside a habitation-style structure, the hall need not have provided domestic accommodation, while smaller gatherings may have also been held in the apsidal Room B (19.25 m2) in Building 1. The likelihood of another building (or buildings) at North Warnborough (Hughes 1981 Hughes, M. (ed.). 1981: Archaeology in Hampshire, Annual Report for 1980, Hampshire County Planning Department, Hampshire County Council and 1982 Hughes, M. (ed.). 1982: Archaeology in Hampshire, Annual Report for 1981, Hampshire County Planning Department, Hampshire County Council) would be consistent with other complexes in Hampshire where corridor houses supplied the private accommodation required, often after the construction of the aisled hall (Cunliffe 2008a Cunliffe, B. 2008a. The vernacular architecture of the region in the Roman period, in B. Cunliffe (ed.) The Danebury Environs Roman Programme: A Wessex Landscape During the Roman Era, Volume 1, Overview, 113-125, Oxford: English Heritage and Oxford University Comm. for Archaeol. Monogr., 49, 118; 2013a Cunliffe, B. 
2013a. 'For men of rank...basilicas': british aisled halls reconsidered, in H. Eckhardt and S. Rippon (eds) Living and Working in the Roman World, 95-109, Portsmouth, RI: Journal of Roman Archaeology Suppl. Ser. 95, 101).

While the finds cannot be related to the identified structural phases (and often not even to the relevant rooms), Liddell did list most of the finds from each building. A limestone loom weight, one limestone and three shale spindle whorls, and two bone shuttles support possible wool-working. Horses, represented by horse shoes and a bit, may have been used for transport or traction. Keys, padlocks, and a steelyard arm suggest the presence of goods of possible monetary value on site. Items related to adornment and appearance included one shale and one copper-alloy bracelet, two copper-alloy finger rings, two faience beads, and a bone comb. There is also some evidence of literacy and written communication in the form of a pot incised post-firing ('PERIGRINI'), a tile cemented into the floor of Room D with indecipherable writing, two possible iron styli, and a second- or third-century wax spatula with a handle depicting Minerva recorded in the same field by the Portable Antiquities Scheme (HAMP-4EB6C5). Each of these represents a different form of literacy, but the wax spatula and possible styli suggest integration into wider social or economic networks.

Analyses of the original architectural design, the proposed agricultural function, and the significance of the architectural impact and geological landscape setting, below, are followed by an assessment of 'developed' form and late-Roman transformation, including engagement with previous interpretations of function and gendered space.

Original Significance

The size of the internal space of this aisled hall can hardly be overstated. For example, calculations of necessary floor space for fire regulations in modern public areas range from c. 0.3 to $7 \mathrm{~m} 2 \mathrm{per}$ person, which would produce a range of 58 to 1366 people that could safely occupy the open space of the Phase 1a hall (calculated by conservatively excluding the areas of Rooms $K$ and $M / N$ ). The vast internal areas of aisled halls indicate a function of providing space for large groups of people intended in their original designs (Cunliffe 2008a Cunliffe, B. 2008a. The vernacular architecture of the region in the Roman period, in B. Cunliffe (ed.) The Danebury Environs Roman Programme: A Wessex Landscape During the Roman Era, Volume 1, Overview, 113-125, Oxford: English Heritage and Oxford University Comm. for Archaeol. Monogr., 49). There may be a functional and behavioural association between aisled halls and a tradition of communal feasting that is represented in the LPRIA by cauldrons, cauldron chains, and large deposits of animal bones (Black 1994, 106-107).

It has been argued that elaborated houses and baths, especially those within planned/monumental groups with an emphasis on a central axis and symmetry, are representative of their designers' desire to emulate Classical architectural forms (Ellis 1995 Ellis, S. 1995. Classical reception rooms in Romano-British houses, Britannia 26, 163-178; Smith 1997 Smith, J.T. 1997. Roman Villas: A Study in Social Structure, London: Routledge). Large, architecturally elaborated communal spaces are often 
viewed as reception rooms for the morning salutatio or annual patron-client meetings (Cunliffe 2008b Cunliffe, B. 2008b. Some thoughts on aisled halls, in B. Cunliffe (ed.) The Danebury Environs Roman Programme: A Wessex Landscape During the Roman Era, Volume 1, Overview, 126-129, Oxford: English Heritage and Oxford University Comm. for Archaeol. Monogr., 49, 126; Ellis 1995 Ellis, S. 1995. Classical reception rooms in Romano-British houses, Britannia 26, 163-178, 166). While the rooms on either end of the hall bear similarities to cottage and winged corridor buildings elsewhere, possibly suggesting that they provided accommodation or areas for private business, if one looks for spaces where imported 'Roman' patron-client relationships could be enacted, one can find them, but would these spaces be interpreted with such specific social functions without reference to classical texts that may have no bearing on society in Roman Britain? It may be unwarranted to map these foreign behaviours and social hierarchies onto the use of a structural type that is so characteristic of British vernacular architecture.

Questioning the agricultural association

The aisled hall at North Warnborough has been squeezed into the 'agricultural' category through two aspects of its plan. Firstly, the 'badly built loose flint walls' (Liddell 1931 Liddell, D.M. 1931. Notes on two excavations in Hampshire, Proc. of the Hampshire Field Club and Archaeol. Soc., 10, 224-236, 233) in the southeastern aisle were proposed as supports for a granary (Illus. 2, V; Applebaum 1972 Applebaum, S. 1972. Roman Britain, in H.P.R. Finberg (ed.) The Agrarian History of England and Wales I:II (AD 43-1042), 3-270, Cambridge: Cambridge University Press), which was repeated by others (Hingley 1989 Hingley, R. 1989. Rural Settlement in Roman Britain, London: Seaby, Morris 1979 Morris, P. 1979. Agricultural Buildings in Roman Britain, Oxford: Brit. Archaeol. Rep. Brit. Ser., 70). These walls probably suggest some installation, but cannot be linked to a raised support for grain storage without further evidence and, in any case, date to a later structural phase and are not related to the original function. Secondly, the rooms with cobbled floors at the southwestern end of the building (Illus. 2, L3-L4) have been interpreted as 'byres' based on their position and cobbled flooring (Hingley 1989 Hingley, R. 1989. Rural Settlement in Roman Britain, London: Seaby). As these rooms contain no drains or 'mucking out holes' and, as the only surviving entrance to them is through the rear wall of the hall into the southeastern aisle, they are more likely to be related to activities within the hall.

Although aisled halls have often been ascribed an agricultural function-for some combination of housing for labourers, storage/processing of arable produce and fodder, or to house livestock-the imposing façade, the vast internal area, painted walls, and heated room of Building 2 suggest a public space designed to hold large numbers of people and to communicate status. It seems clear that aisled halls containing ovens, corn-dryers, stalls and/or archaeobotanical evidence of crop storage (generally restricted to military and urban sites) and processing are likely to have had agricultural functions, but this structure does not have such features or evidence, despite being broadly contemporaneous with the largely fourth-century pattern of agricultural additions to other known aisled halls. Suggestions that the choice to build an aisled hall may have been equally significant as a way to display and communicate wealth, power, and abundance by symbolising the control of surplus or the large number of agricultural labourers housed (Taylor 2011 Taylor, J. 2011. The Idea of the Villa. Reassessing Villa Development in South-East Britain in N. Royman and T. Derks 
(eds) Villa Landscapes in the Roman North: Economy, Culture, and Lifestyles, 179-194, Amsterdam, Amsterdam University Press, 187-188), perhaps as a way to advertise the size of the resident workforce and the agricultural production of an assumed 'estate' (Collingwood and Richmond 1969 Richmond, I.R. 1969. The plans of Roman villas in Britain, in A.L.F. Rivet (ed.) The Roman Villa in Britain, 49-70, London: Routledge, 112, 147; Oelmann 1921 Oelmann, F. 1921. Die Villa Rustica bei Stahl und Verwandtes, Germania 5, 64-73 and 1928 Oelmann, F. 1928. Hauptvortrag, Romische Villen in Rheinland, Arch Anz., 43, 228-250, 118, 121-122; Smith 1963 Smith, J.T. 1963. RomanoBritish aisled houses, Archaeol. J., 120, 1-30, 9, 13, 1978b Smith, J.T. 1978b. Villas as a key to social structure, in M. Todd (ed.) Studies in the Romano-British Villa, 149-185, Leicester: Leicester University Press and 1997 Smith, J.T. 1997. Roman Villas: A Study in Social Structure, London: Routledge, 23ff), do not appear to apply to the construction of Building 2.

It is impossible to link 'wealth' to 'agricultural wealth' without further information of the wider landscape. While the lack of faunal data from North Warnborough prohibits any analysis of animal husbandry on this site specifically, there is a notable difference between the London basin and the Hampshire Downs in the proportions of major domesticates from the assemblages compiled by Allen (2016 Allen, M. 2016. The South, in A. Smith, M. Allen, T. Brindle, and M. Fulford, The Rural Settlement of Roman Britain, 75-140, London: Society for the Promotion of Roman Studies, Britannia Monogr. Ser., 29, 125, 126, fig. 4.61), who found that cattle make up more than $50 \%$ of the NISP on the vast majority of sites in the London basin, while sheep dominate in the Hampshire Downs. Raising cattle, therefore, may have been more significant than agriculture in this area. Although the identities of the people at this site were likely created and maintained through rural landscape features, little can be said of the immediate environs as regards field systems, routes to grazing, enclosures, or trackways possibly associated with the complex (the National Mapping Programme did not extend this part of Hampshire and cropmarks show more clearly on chalk bedrock than on the clay and sand in this area; Royall 2013 Royall, C. 2013. Hampshire Downlands Mapping Project: Results of NMP Air Photo Analysis in the Central Hampshire Chalk Downs, Truro: Cornwall Council Historic Environment Rep. No. 2013R027, Young 2008 Young, A. 2008. The Aggregate Landscape of Hampshire. Results of NMP Mapping, Truro: Cornwall Council Historic Environment Service Rep. No. 2008R042). Nonetheless, a consideration of the wider physical and archaeological context of this complex adds significant detail to suggest a possible alternative to an agricultural function.

Position and Architectural Impact

Symbolic and physical connection to the River Whitewater valley is suggested by the arrangement of the buildings and relationship to the Calleva-Londinium road. The pavilions at the front of the hall, and the suggested courtyard arrangement, indicate that the complex would have been approached from the northeast. For ease of access from the road, the River Whitewater valley, also on this alignment, would have provided the best route and a trackway running along the river would have forced those approaching to see the aisled hall square onto the wide façade and pavilions. The impressive width (16.7 m) -and, likely, height-of Building 2 may have been enhanced through the use of patterns of stone and brick (as at 15-m-wide Meonstoke, Hants., King and Potter 1990 King, A.C. and Potter, T.W. 1990. A new domestic building-facade from Roman Britain, J. of Roman 
Archaeol., 3, 195-204), the pavillions may have risen to more than one story (cf. reconstruction of Norton Disney, Neal 1982 Neal, D.S. 1982. Romano-British villas: one or two storied?, in P.J. Drury (ed.) Structural Reconstruction: Approaches to the Interpretation of the Excavated Remains of Buildings, 153-171, Oxford: Oxford University Press), and the 'nave' may have supported a raised roof, creating a façade that was not only one of the widest in Britain, but perhaps amongst the tallest. Taking the Meonstoke reconstruction as a guide, Building 2 may have been c. $13 \mathrm{~m}$ tall at the top of a hypothesized raised nave roof.

The height and visibility of Building 2 were significant to its impact, although being situated in a lowlying area, it did not dominate the landscape (Illus. 9). The complex is c. $13 \mathrm{~km}$ southeast of Calleva, c. $10.5 \mathrm{~km}$ south of Roman Calleva-Londinium road, and c. $6 \mathrm{~km}$ east of the Calleva-Noviomagus road. Building 2 would have been visible along a short stretch of the Londinium road northeast of Finchampstead, Berks. (east of Illus. 9) and along a ridge that crosses the Noviomagus road southwest of the complex. Along the River Whitewater valley, however, it would have been intermittently visible along most of the distance south of the Calleva-Londinium road.

Illus. 9. Bedrock geology between Calleva and North Warnborough showing known Roman-period roads and sites (from Allen et al. 2015 Allen, M., Blick, N., Brindle, T. Evans, T., Fulford, M., Holbrook, N., Richards, J.D., and Smith, A. 2015 (updated 2016). The Rural Settlement of Roman Britain: an online resource, Archaeology Data

Service,http://archaeologydataservice.ac.uk/archives/view/romangl/) and areas from which the aisled hall would have been visible (at $13 \mathrm{~m}$ height to a 1.8-m person; M3 motorway removed for processing). Scale 1:100,000. (Topographic data: Crown copyright/database right 2016. An Ordnance Survey/EDINA supplied service.)

Rural settlement and geological setting

The site of these buildings lies on the London Clay (Illus. 9) and the overlying soil in the vicinity is clay, silt, sand, and gravel. The rural sites on the London Clay rarely comprise large, high-status masonry buildings but rather are characterised by industrial installations, modest enclosures with timber and post structures, and evidence of small-scale farming. Very few sites overlie the sands to the northeast, while there is a far greater density to the south, west and southwest, on the more productive soils overlying chalk. No known Roman-period sites (Allen et al. 2015 Allen, M., Blick, N., Brindle, T. Evans, T., Fulford, M., Holbrook, N., Richards, J.D., and Smith, A. 2015 (updated 2016). The Rural Settlement of Roman Britain: an online resource, Archaeology Data Service, http://archaeologydataservice.ac.uk/archives/view/romangl/) lie on the London Clay between Calleva and North Warnborough, but northeast of Calleva there are a number on this geology, all of which are relatively close to known Roman roads. Other Roman-period activity on the London Clay is characterised by small-scale settlement (e.g. LPRIA-early Roman enclosures and post-built structures at Spencer's Wood; Stevens 2005 Stevens, S. 2005. An Archaeological Evaluation (Stage 2) on Land at Basingstoke Road, Spencer's Wood, Reading, Berkshire, Portslade: Archaeology South East, Project No. 1958) and industry (e.g. LPRIA-early Roman iron-working at Riseley Farm, Swallowfield, also on the River Whitewater; Lobb and Morris 1993 Lobb, S.J. and Morris, E.L. 1993. 
Investigation of Late Bronze Age and Iron Age features at Riseley Farm, Swallowfield, Berkshire, Archaeol. J., 74, 37-68).

Rural site distributions have been affected by development, however, which has prompted archaeological discoveries in and around Basingstoke (sites such as Cowdery's Down and Daneshill, see Illus. 9) and Reading to a greater degree than in the more rural area between them. The distribution of metal-detected finds (see Illus. 1) indicates Iron Age and Roman-period activity in areas without identified settlements, especially in the valleys. Small settlements and industrial sites may exist further south towards North Warnborough, but have not been located because of a lack of research- or development-driven survey and excavation. Also, the use of the poorer soils for pasture may negatively impact the discovery of sites not subjected to ploughing.

The chalk bedrock begins just over $1 \mathrm{~km}$ to the south of North Warnborough, possibly suggesting that it was part of a larger holding that included mixed resources of pasture, woodland, and arable. The nearest known burial site-late Roman burials within a large linear 'scoop' feature oriented towards a late Bronze Age/early Iron Age roundhouse and associated with a prehistoric enclosure and ditches of the same date-lies on this chalk c. $2.3 \mathrm{~km}$ to the south (RAF Odiham, Jenkins 1991 Jenkins, A.V.C. 1991. An archaeological investigation of a cropmark at Odiham, Hampshire, Proc. of the Hampshire Field Club and Archaeol. Soc., 46, 5-16) and could be the location for burial of some members of the wider community that used the aisled building at North Warnborough.

All of the nearest high-status Roman-period structures to North Warnborough lie on the higheryielding chalk and sandstone formations ( $8 \mathrm{~km}$ to the southeast at Barley Pound Farm, Crondall (second-fourth-century mosaic; Hoare 1829, 54; Neal and Cosh 2009 Neal, D.S. and Cosh, S.R. 2009. Roman Mosaics of Britain, Volume 3, South-East Britain, Part 1, London: Society of Antiquaries, 170$171,310.1) ; 12 \mathrm{~km}$ to the southeast at Hale Road, Farnham (third-century masonry buildings with hypocausts; Lowther 1955 Lowther, A.W.G. 1955. Report on the excavation, 1946-7, of a Roman site at Farnham, Surrey, Surrey Archaeol. Coll., 54, 47-56); 13 km northwest, west of the Calleva-Venta road, at Manor Farm, Monk Sherborne (third-fourth-century aisled hall and other masonry buildings; Teague 2005 Teague, S. 2005. Manor Farm, Monk Sherborne, Hampshire: archaeological investigations in 1996, Proc. of the Hampshire Field Club and Archaeol. Soc., 60, 64-135); $13.5 \mathrm{~km}$ south at Wyck, Alton (second-fourth-century bathhouse; Cole 1988a Cole, G.H. 1988a. A RomanoBritish bath-house at Wyck, near Alton, Hampshire, Proc. of the Hampshire Field Club and Archaeol. Soc., 44, 25-39); and $27 \mathrm{~km}$ north at Harspeden Wood, northeast of Calleva (third-fourth-century winged corridor building; Ashby 1911 Ashby, T. 1911. A Roman villa near Henley, Archaeol. J., 68, 43-9, Rivers-Moore 1951 Rivers-Moore, C.N. 1951. Further excavations in the Roman house at Harspeden Wood, Henley-on-Thames, Oxoniensia, 16, 23-7)). A possible corn-dryer or kiln and evidence of nearby occupation to the southwest (c. 2.9 km) at Choseley Farm (Morris 1986 Morris, M. 1986. An Iron Age and Romano-British site at Choseley Farm, Odiham: the excavations of Dorothy Liddell, 1937, Proc. of the Hampshire Field Club and Archaeol. Soc., 42, 89-108; Illus. 1), also excavated by Liddell, suggests that there are other small Roman-period sites in the area not yet known. 
One high-status site has been found on the London Clay, however: at Broad Street Common, Worplesdon (Hayman 1994 Hayman, G.N. 1994. An Archaeological Site Evaluation on Land adjoining Barnwood School, Guildford, Woking: Surrey County Council Archaeology Unit, unpublished report; Poulton 2005 Poulton, R. 2005. Excavation near Broad Street Common, Worplesdon, Guildford, in 1994, 1997 and 1998, Surrey Archaeol. Coll., 92, 29-89), c. 23 km east of North Warnborough (possibly on the line of the conjectured Londinium-Venta road). A second-century aisled hall with evidence for grain storage and processing and a corridor building containing mosaic and other pavements there may have been constructed with wealth derived not only from arable farming (perhaps more likely c. $2 \mathrm{~km}$ to the south, where the chalk begins), but also from pasture and woodland on the clay and sand formations (Poulton 2005 Poulton, R. 2005. Excavation near Broad Street Common, Worplesdon, Guildford, in 1994, 1997 and 1998, Surrey Archaeol. Coll., 92, 29-89, 85). Similarly, a complex of large second-fourth-century timber buildings, including a possible aisled hall and building material related to a possible bathhouse, on the sandy Windlesham Formation, at South Farm, Lightwater, Surrey, presents evidence that aisled halls on poor soils could have been associated with non-agricultural industrial activities, in this case, bronze- and iron-working (Cole 1988b Cole, G.H. 1988b. Summary and Guide to the Excavations at South Farm, Lightwater, Surrey 1984-1987, Surrey Heath Archaeological and Heritage Trust, unpublished report). This evidence highlights the rarity of high-status, architecturally elaborated buildings on this geology and the likelihood that those that do exist were the property of rural communities outside of the productive arable areas.

Transformation in Later Phases

Change in communal activities

Internal division of Building 2 with wattle-and-plaster walls defining rooms containing cooking hearths and middens indicates a dramatic change in character and function in the final phases. As in other aisled halls, a portion of the hall was retained, which has been interpreted as a balance between the need for a 'Roman lifestyle'/private space and the continuity of earlier activities requiring communal space (Cunliffe 2008a Cunliffe, B. 2008a. The vernacular architecture of the region in the Roman period, in B. Cunliffe (ed.) The Danebury Environs Roman Programme: A Wessex Landscape During the Roman Era, Volume 1, Overview, 113-125, Oxford: English Heritage and Oxford University Comm. for Archaeol. Monogr., 49, 118; 2013a Cunliffe, B. 2013a. 'For men of rank...basilicas': british aisled halls reconsidered, in H. Eckhardt and S. Rippon (eds) Living and Working in the Roman World, 95-109, Portsmouth, RI: Journal of Roman Archaeology Suppl. Ser. 95, 101).

The creation of a bathhouse, which is one of the larger examples recorded in the region (cf. Cunliffe 2008a Cunliffe, B. 2008a. The vernacular architecture of the region in the Roman period, in B. Cunliffe (ed.) The Danebury Environs Roman Programme: A Wessex Landscape During the Roman Era, Volume 1, Overview, 113-125, Oxford: English Heritage and Oxford University Comm. for Archaeol. Monogr., 49, 124, fig. 3.33), played a part in this transformation, likely indicating that the gatherings now included communal bathing. The expansion of the communal activities carried out in 
the aisled hall into communal bathing indicates a changing interpretation of the same valued traditional activity. Having originally had two hypocaust rooms is unusual and would have required a great deal of fuel to heat, but would have accommodated a larger number of bathers. Bath structures are frequently added adjacent to aisled halls in later phases and such arrangements nearly always include another domestic structure (e.g. a corridor building-Cunliffe 2008a Cunliffe, B. 2008a. The vernacular architecture of the region in the Roman period, in B. Cunliffe (ed.) The Danebury Environs Roman Programme: A Wessex Landscape During the Roman Era, Volume 1, Overview, 113-125, Oxford: English Heritage and Oxford University Comm. for Archaeol. Monogr., 49,125 ) or have not been fully excavated and present the distinct possibility of a separate domestic structure, as is the case at North Warnborough (Hughes 1981 Hughes, M. (ed.). 1981: Archaeology in Hampshire, Annual Report for 1980, Hampshire County Planning Department, Hampshire County Council and 1982 Hughes, M. (ed.). 1982: Archaeology in Hampshire, Annual Report for 1981, Hampshire County Planning Department, Hampshire County Council).

Habitation

Although viewing aisled halls as multi-functional structures has gained in popularity (Cunliffe 2008a Cunliffe, B. 2008a. The vernacular architecture of the region in the Roman period, in B. Cunliffe (ed.) The Danebury Environs Roman Programme: A Wessex Landscape During the Roman Era, Volume 1, Overview, 113-125, Oxford: English Heritage and Oxford University Comm. for Archaeol. Monogr., 49 and b, Taylor 2011 Taylor, J. 2011. The Idea of the Villa. Reassessing Villa Development in SouthEast Britain in N. Royman and T. Derks (eds) Villa Landscapes in the Roman North: Economy, Culture, and Lifestyles, 179-194, Amsterdam, Amsterdam University Press), Building 2 is still often considered to have been constructed as the principal residential structure on its site, with the adjacent building assumed to be a bath suite for the entirety of its existence (e.g. Cunliffe 2008a Cunliffe, B. 2008a. The vernacular architecture of the region in the Roman period, in B. Cunliffe (ed.) The Danebury Environs Roman Programme: A Wessex Landscape During the Roman Era, Volume 1, Overview, 113-125, Oxford: English Heritage and Oxford University Comm. for Archaeol. Monogr., $49,117,119$, fig. 3.29). The later-phase internal divisions at North Warnborough have dominated the discussion and the rooms created have been interpreted as representing the increased social status of an individual, a move away from the pre-Roman egalitarian kin-group, and the emerging 'headman' and stratification of the kin group resident-i.e. rooms providing accommodation for a landlord/bailiff/owner and family and the hall and/or aisles retained for labourers, animals, and agricultural storage and processing, with analogies made to medieval hall/solar arrangement and with 'barn dwellings' in Friesland and Saxony (e.g. Richmond 1955 Richmond, I. 1955. Roman Britain, Harmondsworth: Penguin Books, 112 and 1969 Richmond, I.R. 1969. The plans of Roman villas in Britain, in A.L.F. Rivet (ed.) The Roman Villa in Britain, 49-70, London: Routledge, 65; Collingwood and Richmond 1969 Richmond, I.R. 1969. The plans of Roman villas in Britain, in A.L.F. Rivet (ed.) The Roman Villa in Britain, 49-70, London: Routledge, 149; Ward 1911 Ward, J. 1911. Romano-British Buildings and Earthworks, London: Methuen and Co. Ltd; Smith 1963 Smith, J.T. 1963. RomanoBritish aisled houses, Archaeol. J., 120, 1-30; Applebaum 1972 Applebaum, S. 1972. Roman Britain, in H.P.R. Finberg (ed.) The Agrarian History of England and Wales I:II (AD 43-1042), 3-270, Cambridge: Cambridge University Press). 
In the final phase, when these rooms were constructed, the structure had begun to fall into disrepair, with the painted plaster crumbling from the walls and not replaced, and a midden of oyster shells and other refuse created inside two of the rooms. Arguments for status division are perhaps better suited to aisled halls where the 'high-status/upper end/private' rooms do not contain middens and debris. Such decay suggests changing values of the space and that the communication of social and economic status was no longer one of its primary functions. Late Roman-period lowered status and decreased maintenance of structures-often referred to as 'disuse' or 'squatting' - is known across the Empire and likely indicates changing values and the redirection of wealth away from domestic space (Gerrard 2013 Gerrard, J. 2013. The Ruin of Roman Britain, Cambridge: Cambridge University Press, 165; Esmonde Cleary 1989 Esmonde Cleary, A. S. 1989. The Ending of Roman Britain, London: Batsford, 134) as well as the altered function of the space.

Gendered space

Some have suggested that the division of space within aisled buildings was more likely to have been between humans and animals, and along gender lines, with North Warnborough appearing as the canonical example (Applebaum 1972 Applebaum, S. 1972. Roman Britain, in H.P.R. Finberg (ed.) The Agrarian History of England and Wales I:II (AD 43-1042), 3-270, Cambridge: Cambridge University Press; Black 1987 Black, E.W. 1987. The Roman Villas of South-East England, Oxford: Brit. Archaeol. Rep. Brit. Ser., 171, 79; Hingley 1989 Hingley, R. 1989. Rural Settlement in Roman Britain, London: Seaby, 43-45). Hingley's (1989 Hingley, R. 1989. Rural Settlement in Roman Britain, London: Seaby) discussion of the gendered use of space began the frequent mention of North Warnborough in archaeological literature, although it was the excavator, Liddell, who made the original hypothesis: 'It is interesting to note that while the rooms $\mathrm{O}, \mathrm{P}, \mathrm{S}, \mathrm{T}$, and $\mathrm{K}$ are responsible for the comb, shuttles, spindle-whorls, and all the other feminine appurtenances, most of the spear-heads, keys, padlocks, knives, and ironmongery in general came from the rooms $L$, the corridor $Q$, the courtyard outside, $T$, U, V, and W' (Liddell 1931 Liddell, D.M. 1931. Notes on two excavations in Hampshire, Proc. of the Hampshire Field Club and Archaeol. Soc., 10, 224-236, 235-236; see Illus. 2). This note, along with locations of hearths, was then taken by others as evidence of the gendered differentiation of space without critique of the links between the objects/features listed and gender/gender identities or the lack of information regarding the stratigraphic relationship between the spaces themselves and that of the deposits containing the objects (Applebaum 1972 Applebaum, S. 1972. Roman Britain, in H.P.R. Finberg (ed.) The Agrarian History of England and Wales I:II (AD 43-1042), 3-270, Cambridge: Cambridge University Press, 16-18; Black 1987 Black, E.W. 1987. The Roman Villas of South-East England, Oxford: Brit. Archaeol. Rep. Brit. Ser., 171, 79; Hingley 1989 Hingley, R. 1989. Rural Settlement in Roman Britain, London: Seaby, 44, fig. 18, 45). Subsequent work has questioned the conclusions and recommended reappraisal of the evidence (e.g. Perring 2002 Perring, D. 2002. The Roman House in Britain, London: Routledge, 11-12, 209; Smith 1997 Smith, J.T. 1997. Roman Villas: A Study in Social Structure, London: Routledge, 37).

The application of the hypothesis of gendered space here assumes that the plan represents one phase and that the materials found during excavation were deposited as by-products of and contemporaneous with activities in the structure as shown. There is no recorded relationship, however, between the finds and their contexts in relation to the internal divisions, floor layers, and 
phases of use. The hearths can be linked firmly to the latest phase of use, but, it must be stated that the association between women and food preparation in late Roman Britain is not supported by any evidence. Except for phases of 'disuse' when internal middening became acceptable, floors made of hard-packed chalk or pavements were likely to have been swept clean regularly and only a rapid abandonment might be expected to preserve objects in the areas where they were used and stored. Liddell did not provide the stratigraphic information to relate the artefacts to a phase and, thus, they do not reflect the patterns of quotidian domestic use of space early in or throughout the life-cycle of the building. Even if the stratigraphic evidence were available, it is also well established that rooms and spaces could be employed for different purposes at different times of day or year or by the movement of people, objects, and furniture.

Additionally, there is no consensus on which objects might represent true gendered activities among rural communities in the different regions of Britain at different times. No link has been made in late Romano-British contexts between wool-working and women or girls, although the spinning implements may generally suggest women's work to those familiar with the literary ideal of the Roman matron, spinning in her atrium. Also, as Allison (2004 Allison, P.M. 2004. Pompeian Households: An Analysis of the Material Culture, Los Angeles: The Cotsen Institute of Archaeology, UCLA, Monogr., 42, 156) notes, 'the term textor indicates that males also engaged in weaving...From the current state of our knowledge, there seems little reason to assume that males' involvement in this industry did not include the production that took place within the household'. Associating Roman artefacts with gender is a difficult task, hindered most by our own modern values (AllasonJones 1995 Allason-Jones, L. 1995. Sexing Small Finds, in P. Rush (ed.) Theoretical Roman Archaeology: Second Conference Proceedings, Worldwide Archaeology Series, 22-32, Aldershot, Hampshire: Ashgate Publishing Co, 22-28; Allison 2004 Allison, P.M. 2004. Pompeian Households: An Analysis of the Material Culture, Los Angeles: The Cotsen Institute of Archaeology, UCLA, Monogr., 42, 156-157), but also by the lack of apparent strict gender associations with materials in burial assemblages. Objects worn in funerary contexts can be linked to sexed bodies and thereby add some weight to the arguments, but the analogy must be robustly linked regionally, socially, and chronologically. While some brooches, unguentaria/balsamaria, and needles may have been used primarily by one gender in some regions of Britain (Allison 2015 Allison, P.M. 2015. Characterizing Roman artifacts to investigate gendered practices in contexts without sexed bodies, American J. of Archaeol., 119 (1), 103-123, Eckhardt 2005 Eckardt, H. 2005. The social distribution of Roman artefacts: the case of nail cleaners and brooches in Britain, J. of Roman Archaeol., 18, 139-160), the nearest burial area in space and time to North Warnborough at RAF Odiham (Illus. 1; Jenkins 1991 Jenkins, A.V.C. 1991. An archaeological investigation of a cropmark at Odiham, Hampshire, Proc. of the Hampshire Field Club and Archaeol. Soc., 46, 5-16) revealed the common paucity of material culture in late Roman burials. Ultimately, while investigation of gender and gender identities is a welcome field of inquiry, conclusions about gendered activities and spaces cannot be supported from the evidence at North Warnborough.

\section{DISCUSSION}

Interpreting aisled halls as ancillary agricultural or industrial buildings sometimes later converted to residences ignores the fact that aisled halls are often the most impressive in a complex for their size, 
position, and architectural elaboration (Cunliffe 2008a Cunliffe, B. 2008a. The vernacular architecture of the region in the Roman period, in B. Cunliffe (ed.) The Danebury Environs Roman Programme: A Wessex Landscape During the Roman Era, Volume 1, Overview, 113-125, Oxford: English Heritage and Oxford University Comm. for Archaeol. Monogr., 49; 2013a Cunliffe, B. 2013a. 'For men of rank...basilicas': british aisled halls reconsidered, in H. Eckhardt and S. Rippon (eds) Living and Working in the Roman World, 95-109, Portsmouth, RI: Journal of Roman Archaeology Suppl. Ser. 95). Cunliffe's observation that aisled halls were often the first masonry-founded buildings to be constructed on rural sites serves to illustrate their significance and the commitment to the effort and financial outlay required to build them. Wooden aisled halls preceding reconstruction in stone represent possible evidence of the value and continued function of such communal space (Cunliffe 2008a Cunliffe, B. 2008a. The vernacular architecture of the region in the Roman period, in B. Cunliffe (ed.) The Danebury Environs Roman Programme: A Wessex Landscape During the Roman Era, Volume 1, Overview, 113-125, Oxford: English Heritage and Oxford University Comm. for Archaeol. Monogr., 49), but need not indicate that the inhabitants were weakly integrated into the economy or society of the province, resistant to change and conservative.

By approaching the hall from the most impressive angle forced through the arrangement of buildings, the designers have created a 'processional theatre' to display the complex to its best advantage (Taylor 2011 Taylor, J. 2011. The Idea of the Villa. Reassessing Villa Development in South-East Britain in N. Royman and T. Derks (eds) Villa Landscapes in the Roman North: Economy, Culture, and Lifestyles, 179-194, Amsterdam, Amsterdam University Press, 186-187). The distance from Calleva and visibility of the complex within the River Whitewater valley and not from the Roman roads suggests that the display of status and wealth to tenants/peers of the local rural community was more significant than the concerns and interests of urban communities and political authority (cf. lack of visibility to transient road-users of the Roman villa and barrows at Bartlow, Cambridgeshire, Eckardt 2009 Eckardt, H. 2009. Roman barrows and their landscape context: a GIS case study at Bartlow, Cambridgeshire, Britannia, 40,65-98). Such an alignment and cohesion among rural communities was likely far more significant than the elite/urban associations often assumed for high-status rural sites (Allen 2016 Allen, M. 2016. The South, in A. Smith, M. Allen, T. Brindle, and M. Fulford, The Rural Settlement of Roman Britain, 75-140, London: Society for the Promotion of Roman Studies, Britannia Monogr. Ser., 29, 115).

The especially Romano-British nature of aisled buildings and evidence for continuity of function from the LPRIA supports the ongoing significance of rurally based social networks and the place that these structures had in negotiating and maintaining them (Taylor 2001 Taylor, J. 2001. Rural society in Roman Britain, in S. James and M. Millett (eds) Britons and Romans: Advancing an Archaeological Agenda, 46-59, York: Council for British Archaeology, Research Report 125, 46). The complex at North Warnborough can be viewed as an example of high-status, rural communal space, serving a group of people bound by their dependence on each other in an area of poor crop yield. The evidence for spinning and weaving, in the form of loom weights, spindle whorls and shuttles, may support sheep farming as one of the primary sources of income and the building may represent the prestige of owning land and livestock (Taylor 2013 Taylor, J. 2013. Encountering romanitas: characterising the role of agricultural communities in Roman Britain, Britannia 44, 171-490), although the relationship between the phasing and objects makes it impossible to link wool processing with funds for the original construction. The link between mixed-resource exploitation on poorer soils and aisled halls in this area suggests that North Warnborough was significant to the 
creation of a cohesive community identity among people dependent on one another for economic success. High-status sites on poor soils may have held a special significance as the centre of a community of inter-dependent specialists not engaged in intensive surplus-producing farming, but rather in grazing animals, wood coppicing, quarrying, and industrial production; those industries requiring water may have been concentrated within the River Whitewater valley. Such a position within a wider community of inter-dependent industries would possibly serve to explain the communal functions of the aisled hall-and communal bathing in the later phases-for status display, largesse, and bringing together the people engaged in managing these different activities.

Although the evidence is limited in this area, there are indications that this was a landscape also structured by memory and a link between group identity and place. The location chosen for the individuals buried in the fourth century at RAF Odiham appears orientated towards and related to (?visible) late Bronze Age/early Iron Age remains there. While the distance between the buildings at North Warnborough and this burial site is probably too great to demonstrate a link between the inhabitants and those people burying their dead, the relationship between these burials and the local landscape is significant and provides information about the wider community. The location may have been chosen for burial because of the significance of the place and a link to the past, which could physically and symbolically connect the late Roman-period people with the social memory of place, an illusion of continuity and ancestral links, and the use of the land itself. Combined with the North Warnborough structures' evidence for communal activities and the bond between people reinforced by such gatherings, the creation of a sense of unity and connection to the land and the past likely formed part of the construction of the rural group identity of the community using these buildings.

Rural communities may have used aisled halls to drive cultural change within this province and to create a recognizable character of rural provincial identity intimately connected to the landscape and social groups, neither derived from nor reflecting traditional 'Roman' or urban material changes. The agency of the vast majority of the population, who did not live in cities, is demonstrated through such ability to create new material culture in a rural provincial context with a specific knowledge of what they were inventing, adopting and rejecting as a way of negotiating and constructing identities that did not rely on identifying as either 'Roman' or 'indigenous'. The choice of this particular architectural form, so characteristic of the countryside of Roman Britain, was a conscious method of communicating the owners'/inhabitants' inclusion in the land-owning rural peer group and served as a space for creating and reinforcing hierarchies and social relationships with kin, tenants and peers. Whether an individual, family, or group of people owned the complex is difficult to say, but, within aisled halls, communal ownership may be more likely (Smith 1997 Smith, J.T. 1997. Roman Villas: A Study in Social Structure, London: Routledge, 275-277). The link between place, memory, and community at North Warnborough suggests that high-status aisled buildings on poor soils are deserving of greater attention with regard to their special function in the construction of rural provincial identities and reinforcement of group identities through communal activities.

\section{ACKNOWLEDGEMENTS}


Kind thanks to Alan Whitney of the Hampshire Historic Environment Record for providing data, to David Allen of Hampshire Museums for providing access to archive materials, to Mike Fulford and Martin Millett for reading and commenting on drafts, and to the anonymous reviewers for their helpful suggestions.

\section{REFERENCES}

Allason-Jones, L. 1995. Sexing Small Finds, in P. Rush (ed.) Theoretical Roman Archaeology: Second Conference Proceedings, Worldwide Archaeology Series, 22-32, Aldershot, Hampshire: Ashgate Publishing Co

Allen, M. 2016. The South, in A. Smith, M. Allen, T. Brindle, and M. Fulford, The Rural Settlement of Roman Britain, 75-140, London: Society for the Promotion of Roman Studies, Britannia Monogr. Ser., 29

Allen, M., Blick, N., Brindle, T. Evans, T., Fulford, M., Holbrook, N., Richards, J.D., and Smith, A. 2015 (updated 2016). The Rural Settlement of Roman Britain: an online resource, Archaeology Data Service, http://archaeologydataservice.ac.uk/archives/view/romangl/

Allison, P.M. 2004. Pompeian Households: An Analysis of the Material Culture, Los Angeles: The Cotsen Institute of Archaeology, UCLA, Monogr., 42

Allison, P.M. 2015. Characterizing Roman artifacts to investigate gendered practices in contexts without sexed bodies, American J. of Archaeol., 119 (1), 103-123

Applebaum, S. 1972. Roman Britain, in H.P.R. Finberg (ed.) The Agrarian History of England and Wales I:II (AD 43-1042), 3-270, Cambridge: Cambridge University Press

Ashby, T. 1911. A Roman villa near Henley, Archaeol. J., 68, 43-9

Black, E.W. 1987. The Roman Villas of South-East England, Oxford: Brit. Archaeol. Rep. Brit. Ser., 171

Cole, G.H. 1988a. A Romano-British bath-house at Wyck, near Alton, Hampshire, Proc. of the Hampshire Field Club and Archaeol. Soc., 44, 25-39

Cole, G.H. 1988b. Summary and Guide to the Excavations at South Farm, Lightwater, Surrey 19841987, Surrey Heath Archaeological and Heritage Trust, unpublished report

Collingwood, R.G. and Richmond, I. 1969. The Archaeology of Roman Britain, London: Methuen

Collingwood, R. and Taylor, M.V. 1931. Roman Britain in 1930, J. of Roman Stud., 21, 215-250

Colt Hoare, R. 1829. VI. Observations upon four mosaic pavements discovered in the county of Hants; by Sir Richard Colt Hoare, Bart. F.R.S. and S.A. in a Letter to Nicholas Carlisle, Esq. F.R.S. Secretary, Archaeologia, 22, 49-54

Cunliffe, B. 2013b. The Roman Villa at Brading, Isle of Wight, Oxford: Oxford University School of Archaeol. Monogr. 48

Cunliffe, B. 2008a. The vernacular architecture of the region in the Roman period, in B. Cunliffe (ed.) The Danebury Environs Roman Programme: A Wessex Landscape During the Roman Era, Volume 1, 
Overview, 113-125, Oxford: English Heritage and Oxford University Comm. for Archaeol. Monogr., 49

Cunliffe, B. 2008b. Some thoughts on aisled halls, in B. Cunliffe (ed.) The Danebury Environs Roman Programme: A Wessex Landscape During the Roman Era, Volume 1, Overview, 126-129, Oxford: English Heritage and Oxford University Comm. for Archaeol. Monogr., 49

Cunliffe, B. 2013a. 'For men of rank...basilicas': british aisled halls reconsidered, in H. Eckhardt and S. Rippon (eds) Living and Working in the Roman World, 95-109, Portsmouth, RI: Journal of Roman Archaeology Suppl. Ser. 95

Eckardt, H. 2005. The social distribution of Roman artefacts: the case of nail cleaners and brooches in Britain, J. of Roman Archaeol., 18, 139-160

Eckardt, H. 2009. Roman barrows and their landscape context: a GIS case study at Bartlow, Cambridgeshire, Britannia, 40, 65-98

Ellis, S. 1995. Classical reception rooms in Romano-British houses, Britannia 26, 163-178,

Esmonde Cleary, A. S. 1989. The Ending of Roman Britain, London: Batsford

Gerrard, J. 2013. The Ruin of Roman Britain, Cambridge: Cambridge University Press,

Graham, K.D. 1971. The Roman tile kiln at Scotland Farm, near Hook, Hants, J. of the Farnham Museum Soc., 1, 22-29

Hadman, J. 1978. Aisled buildings in Roman Britain, in M. Todd (ed.) Studies in Romano-British Villas, 187-195, Leicester: Leicester University Press

Hayman, G.N. 1994. An Archaeological Site Evaluation on Land adjoining Barnwood School, Guildford, Woking: Surrey County Council Archaeology Unit, unpublished report

Hingley, R. 1989. Rural Settlement in Roman Britain, London: Seaby

Hughes, M. (ed.). 1981: Archaeology in Hampshire, Annual Report for 1980, Hampshire County Planning Department, Hampshire County Council

Hughes, M. (ed.). 1982: Archaeology in Hampshire, Annual Report for 1981, Hampshire County Planning Department, Hampshire County Council

Jenkins, A.V.C. 1991. An archaeological investigation of a cropmark at Odiham, Hampshire, Proc. of the Hampshire Field Club and Archaeol. Soc., 46, 5-16

King, A.C. and Potter, T.W. 1990. A new domestic building-facade from Roman Britain, J. of Roman Archaeol., 3, 195-204

Liddell, D.M. 1929. Report on the Excavation of a Roman Building at Lodge Farm, North Warnborough, Hants., Hampshire County Museums Headquarters Archives, unpublished manuscript Liddell, D.M. 1931. Notes on two excavations in Hampshire, Proc. of the Hampshire Field Club and Archaeol. Soc., 10, 224-236

Lobb, S.J. and Morris, E.L. 1993. Investigation of Late Bronze Age and Iron Age features at Riseley Farm, Swallowfield, Berkshire, Archaeol. J., 74, 37-68 
Lowther, A.W.G. 1955. Report on the excavation, 1946-7, of a Roman site at Farnham, Surrey, Surrey Archaeol. Coll., 54, 47-56

Millett, M. 1990. The Romanization of Britain, Cambridge: Cambridge University Press

Morris, M. 1986. An Iron Age and Romano-British site at Choseley Farm, Odiham: the excavations of Dorothy Liddell, 1937, Proc. of the Hampshire Field Club and Archaeol. Soc., 42, 89-108

Morris, P. 1979. Agricultural Buildings in Roman Britain, Oxford: Brit. Archaeol. Rep. Brit. Ser., 70

Neal, D.S. and Cosh, S.R. 2009. Roman Mosaics of Britain, Volume 3, South-East Britain, Part 1, London: Society of Antiquaries

Neal, D.S. 1982. Romano-British villas: one or two storied?, in P.J. Drury (ed.) Structural Reconstruction: Approaches to the Interpretation of the Excavated Remains of Buildings, 153-171, Oxford: Oxford University Press

Oelmann, F. 1921. Die Villa Rustica bei Stahl und Verwandtes, Germania 5, 64-73

Oelmann, F. 1928. Hauptvortrag, Romische Villen in Rheinland, Arch Anz., 43, 228-250

Perring, D. 2002. The Roman House in Britain, London: Routledge

Poulton, R. 2005. Excavation near Broad Street Common, Worplesdon, Guildford, in 1994, 1997 and 1998, Surrey Archaeol. Coll., 92, 29-89

Richmond, I.A. 1932. Irish analogies for the Romano-British barn dwelling, J. of Roman Stud., 22, 96106 ,

Richmond, I. 1955. Roman Britain, Harmondsworth: Penguin Books

Richmond, I.R. 1969. The plans of Roman villas in Britain, in A.L.F. Rivet (ed.) The Roman Villa in Britain, 49-70, London: Routledge

Rivers-Moore, C.N. 1951. Further excavations in the Roman house at Harspeden Wood, Henley-onThames, Oxoniensia, 16, 23-7

Rogers, A. 2015. The Archaeology of Roman Britain: Biography and Identity, New York: Routledge Royall, C. 2013. Hampshire Downlands Mapping Project: Results of NMP Air Photo Analysis in the Central Hampshire Chalk Downs, Truro: Cornwall Council Historic Environment Rep. No. 2013 R027

Smith, A. 2016. Buildings in the countryside, in A. Smith, M. Allen, T. Brindle, and M. Fulford, The Rural Settlement of Roman Britain, 44-74, London: Society for the Promotion of Roman Studies, Britannia Monogr. Ser., 29

Smith, A., Allen, M., Brindle, T., and Fulford, M. 2016. The Rural Settlement of Roman Britain, London: Society for the Promotion of Roman Studies, Britannia Monogr. Ser., 29

Smith, J.T. 1963. Romano-British aisled houses, Archaeol. J., 120, 1-30

Smith, J.T. 1978a. Hall or yards? A problem of villa interpretation, Britannia, 9, 351-358

Smith, J.T. 1978b. Villas as a key to social structure, in M. Todd (ed.) Studies in the Romano-British Villa, 149-185, Leicester: Leicester University Press

Smith, J.T. 1997. Roman Villas: A Study in Social Structure, London: Routledge 
Stevens, S. 2005. An Archaeological Evaluation (Stage 2) on Land at Basingstoke Road, Spencer's Wood, Reading, Berkshire, Portslade: Archaeology South East, Project No. 1958

Taylor, J. 2001. Rural society in Roman Britain, in S. James and M. Millett (eds) Britons and Romans: Advancing an Archaeological Agenda, 46-59, York: Council for British Archaeology, Research Report 125

Taylor, J. 2013. Encountering romanitas: characterising the role of agricultural communities in Roman Britain, Britannia 44, 171-490

Taylor, J. 2011. The Idea of the Villa. Reassessing Villa Development in South-East Britain in N. Royman and T. Derks (eds) Villa Landscapes in the Roman North: Economy, Culture, and Lifestyles, 179-194, Amsterdam, Amsterdam University Press

Teague, S. 2005. Manor Farm, Monk Sherborne, Hampshire: archaeological investigations in 1996, Proc. of the Hampshire Field Club and Archaeol. Soc., 60, 64-135

Todd, M. 1992. Aisled halls in Roman Gaul, Oxford J. of Archaeol., 11(3), 369-372

Ward, J. 1911. Romano-British Buildings and Earthworks, London: Methuen and Co. Ltd

Young, A. 2008. The Aggregate Landscape of Hampshire. Results of NMP Mapping, Truro: Cornwall Council Historic Environment Service Rep. No. 2008 R042

Author information

Lacey M. Wallace

Lacey M. Wallace, School of History and Heritage, College of Arts, University of Lincoln, Brayford Pool, Lincoln LN6 7TS. Email: Iwallace@lincoln.ac.uk 


\section{Figures \& data}

Illus. 1. Location of the site at Lodge Farm, North Warnborough in relation to Calleva Atrebatum (Silchester) and known Roman-period roads and settlements (including data from Allen et

al. 2015Allen, M., Blick, N., Brindle, T. Evans, T., Fulford, M., Holbrook, N., Richards, J.D., and Smith, A. 2015 (updated 2016). The Rural Settlement of Roman Britain: an online resource, Archaeology Data

Service,http://archaeologydataservice.ac.uk/archives/view/romangl/[Google

Scholar] and the Portable Antiquities Scheme, 15 August 2017). Scale 1:100,000.

(Topographic and geological data: Crown copyright/database right 2016. An Ordnance Survey/EDINA supplied service.)

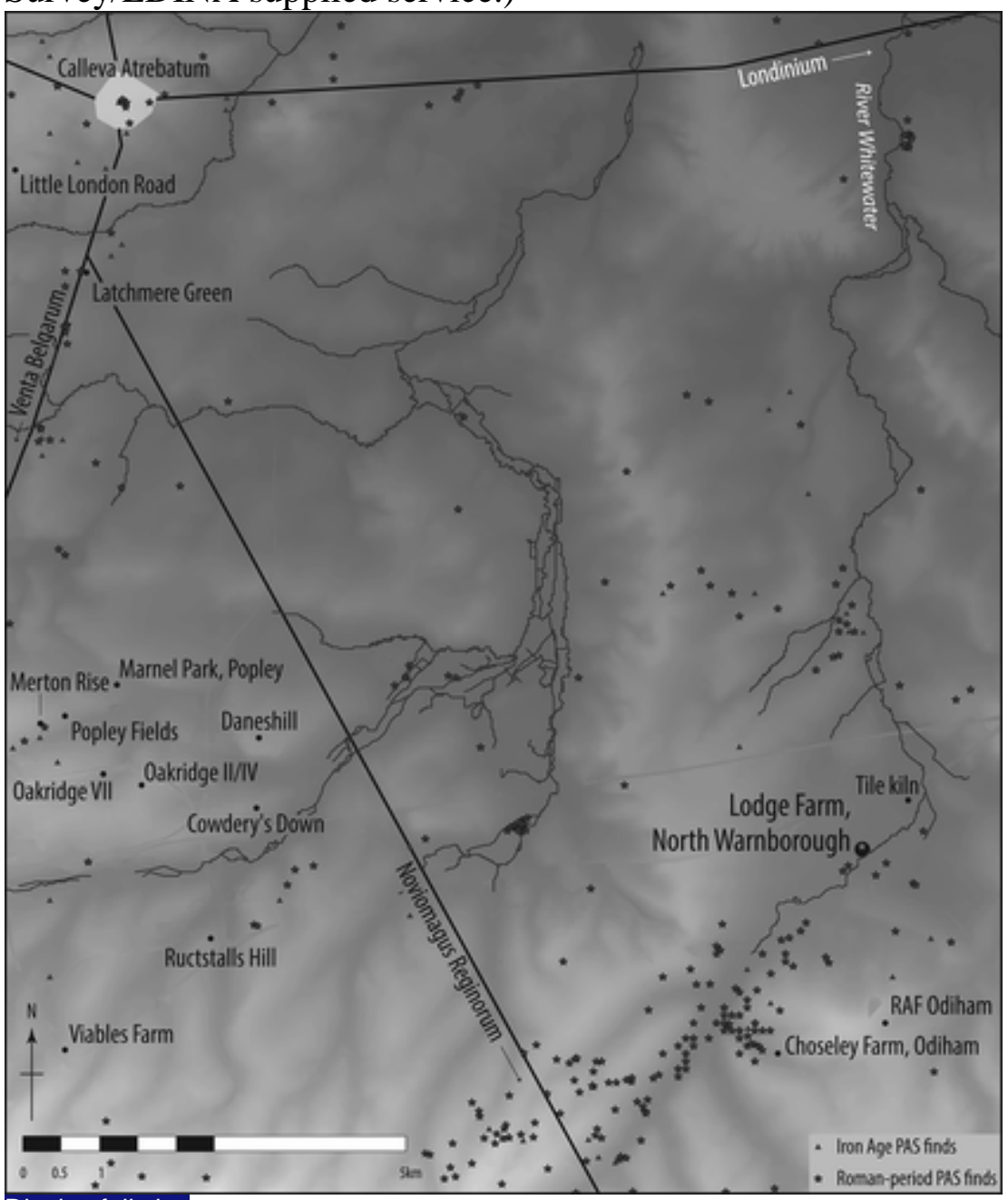

Display full size

Illus. 2. Multi-phase plan (after Liddell 1931Liddell, D.M. 1931. Notes on two excavations in Hampshire, Proc. of the Hampshire Field Club and Archaeol. Soc., 10, 224-236[Google Scholar], plate IV and Collingwood and Taylor 1931Collingwood, R. and Taylor, M.V. 1931. Roman Britain in 1930, J. of Roman Stud., 21, 215-250[Google Scholar], 243, fig. 24). 


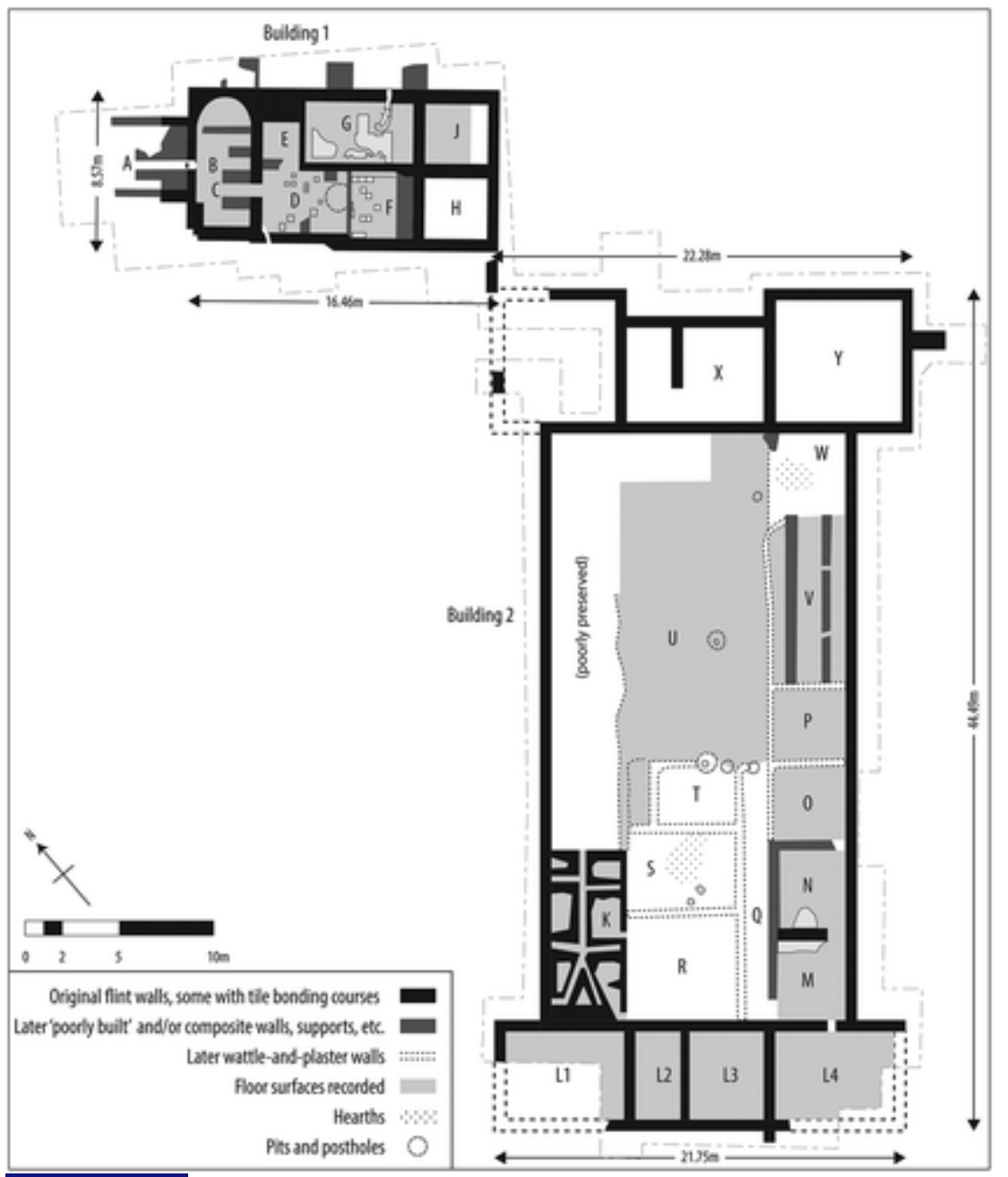

\section{Display full size}

Illus. 3. Phase 1a (after Liddell 1931Liddell, D.M. 1931. Notes on two excavations in Hampshire, Proc. of the Hampshire Field Club and Archaeol. Soc., 10, 224-236[Google Scholar], plate IV and Collingwood and Taylor 1931Collingwood, R. and Taylor, M.V. 1931. Roman Britain in 1930, J. of Roman Stud., 21, 215-250[Google Scholar], 243, fig. 24). Positions of Building 2 aisle posts estimated from the northeasternmost extant posthole shown here. (NB: Hypocaust $\mathrm{K}$ and the wall between Rooms $\mathrm{M}$ and $\mathrm{N}$ were proposed as primary by Liddell (1931Liddell, D.M. 1931. Notes on two excavations in Hampshire, Proc. of the Hampshire Field Club and Archaeol. Soc., 10, 224-236[Google Scholar]), but may belong to Phase 1b (Illus. 4).) It is likely that the floors of Building 2 were either of chalk (as the hypocaust, $\mathrm{K}$ ) or stamped earth. Scarlet and blue wall plaster found beneath later floor levels in the hall indicates decoration likely to belong to this phase. 


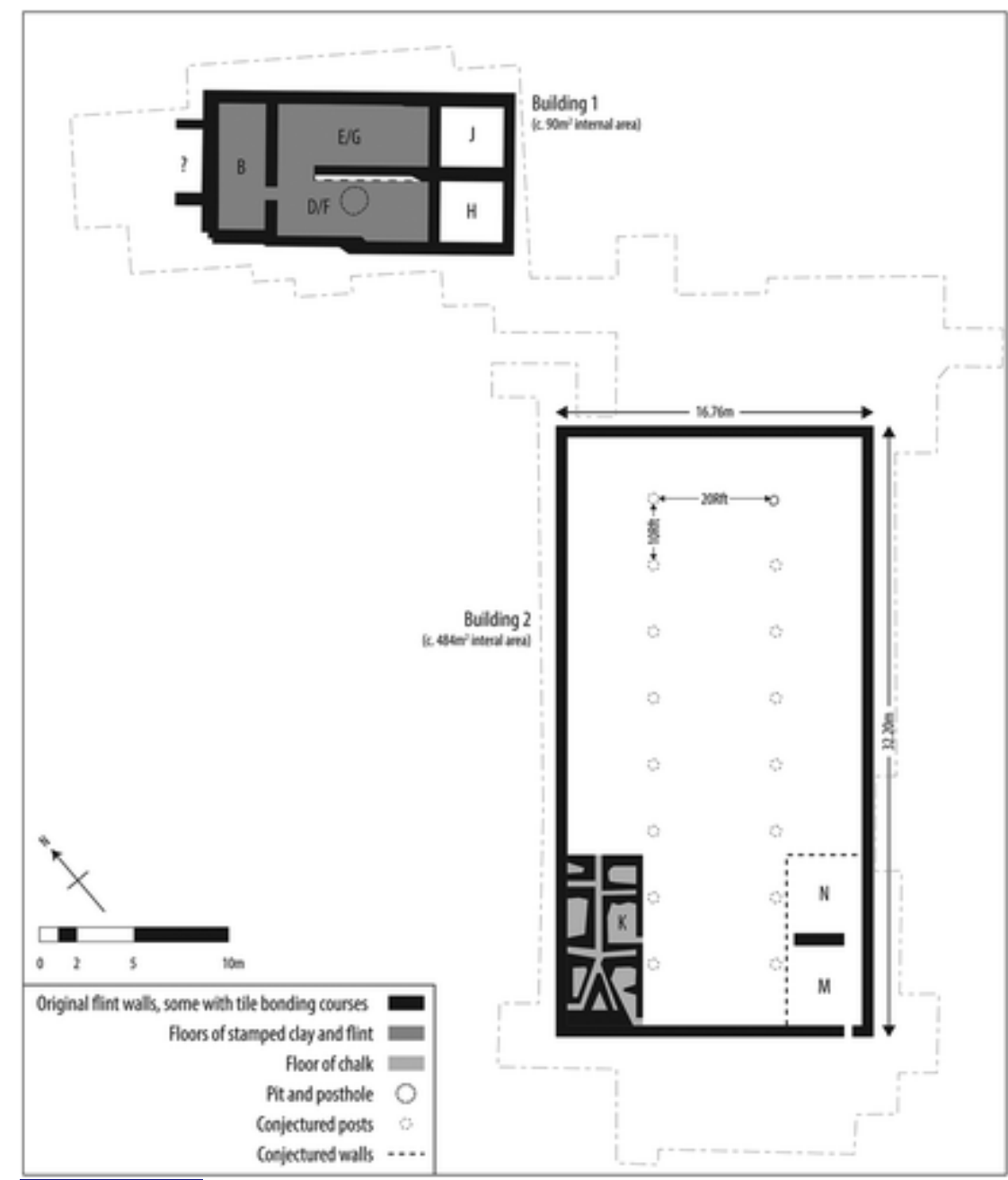

\section{Display full size}

Illus. 4. Phase 1b (after Liddell 1931Liddell, D.M. 1931. Notes on two excavations in Hampshire, Proc. of the Hampshire Field Club and Archaeol. Soc., 10, 224-236[Google Scholar], plate IV and Collingwood and Taylor 1931Collingwood, R. and Taylor, M.V. 1931. Roman Britain in 1930, J. of Roman Stud., 21, 215-250[Google Scholar], 243, fig. 24). 


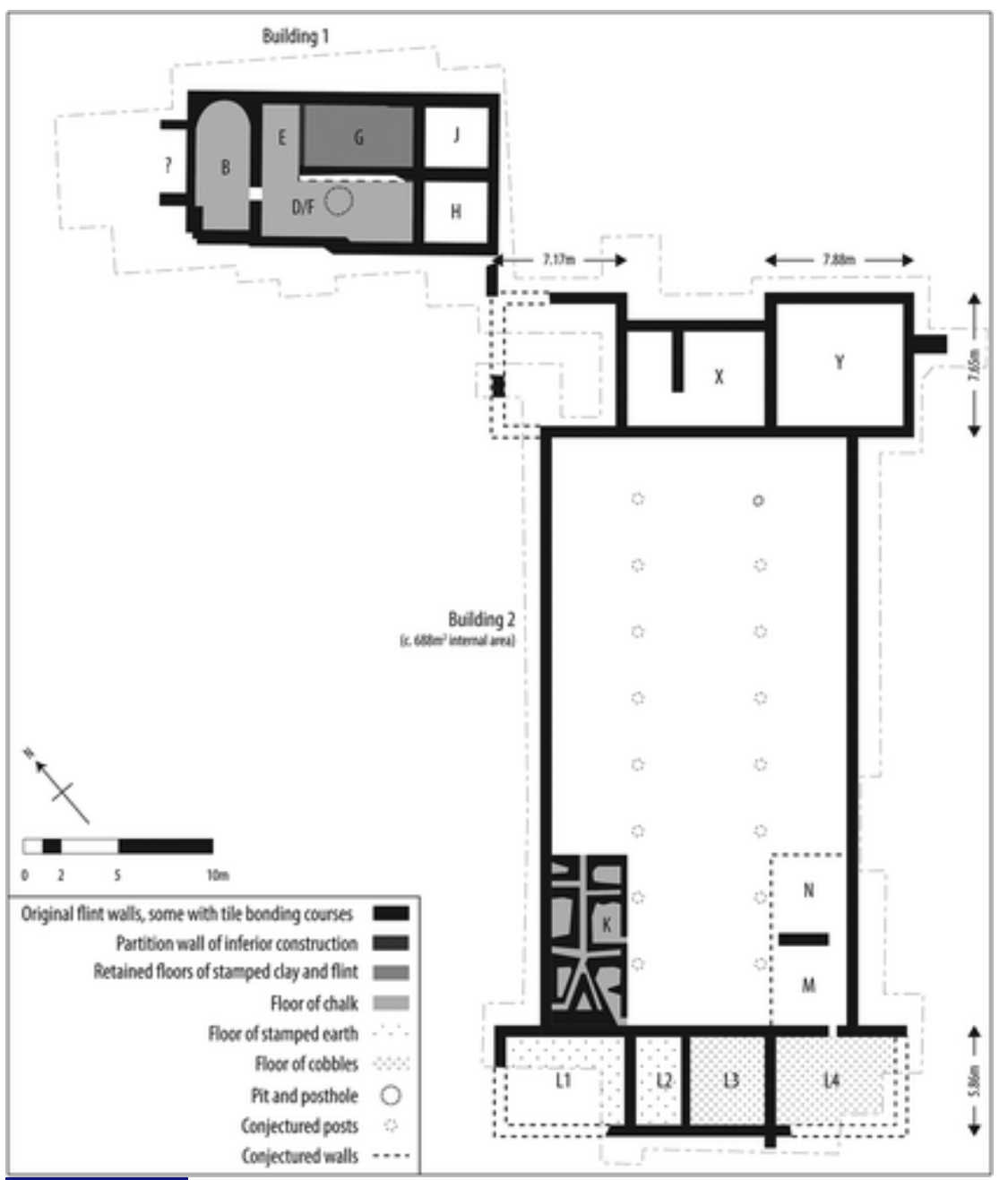

\section{Display full size}

Illus. 5. Phase 2a (after Liddell 1931Liddell, D.M. 1931. Notes on two excavations in Hampshire, Proc. of the Hampshire Field Club and Archaeol. Soc., 10, 224-236[Google Scholar], plate IV and Collingwood and Taylor 1931Collingwood, R. and Taylor, M.V. 1931. Roman Britain in 1930, J. of Roman Stud., 21, 215-250[Google Scholar], 243, fig. 24). The wall separating Building 1 Rooms D and F was partially constructed across the open pit. The walls of Room B were replastered in pink. 


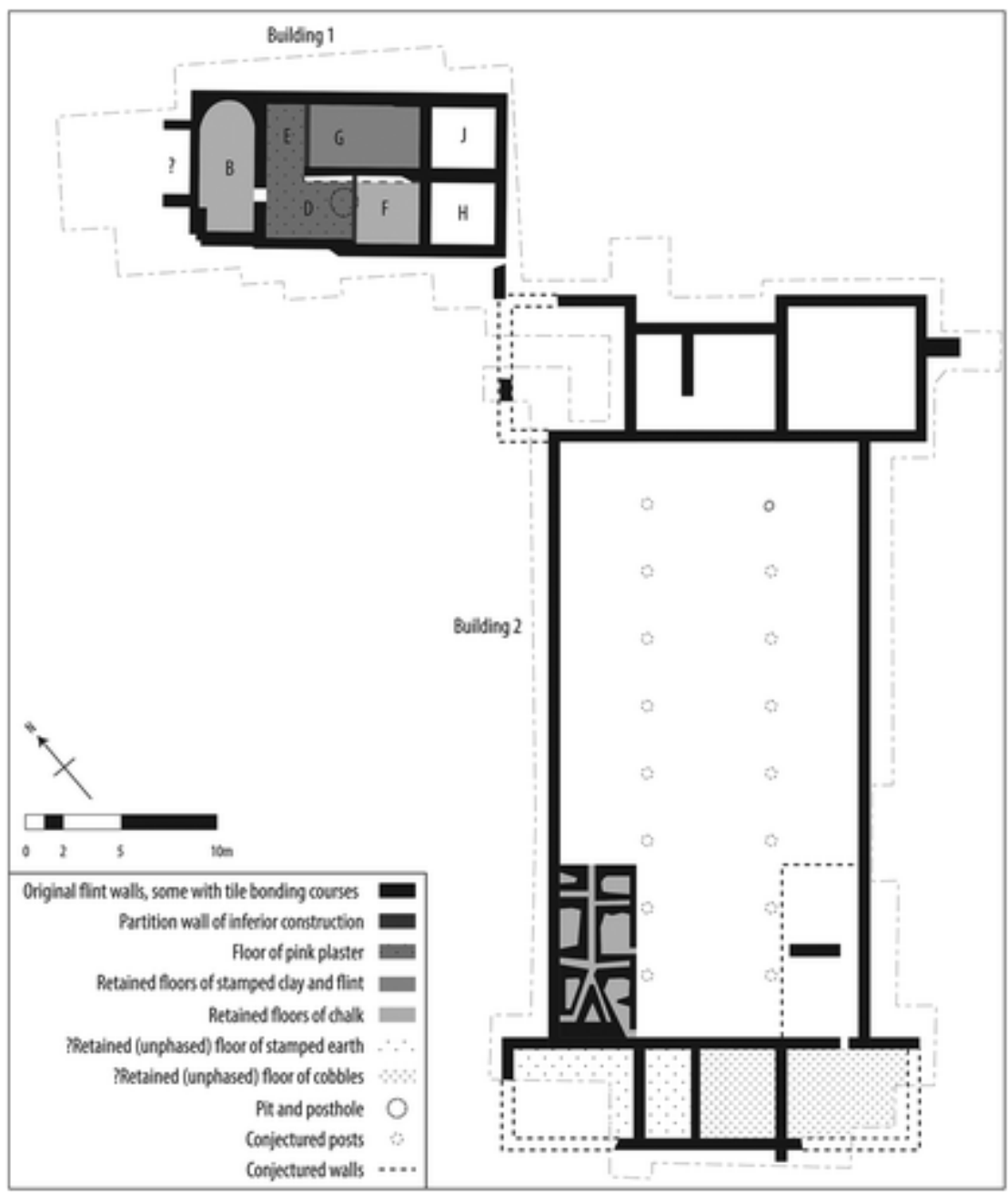

\section{Display full size}

Illus. 6. Phase 2b (after Liddell 1931Liddell, D.M. 1931. Notes on two excavations in Hampshire, Proc. of the Hampshire Field Club and Archaeol. Soc., 10, 224-236[Google Scholar], plate IV and Collingwood and Taylor 1931Collingwood, R. and Taylor, M.V. 1931. Roman Britain in 1930, J. of Roman Stud., 21, 215-250[Google Scholar], 243, fig. 24). Building 1 Room $D$ had white wall plaster with bands of black and red and a floral scroll design in red, brown, yellow, and black (Illus. 7), and Room F had dark rose-coloured plaster walls. 


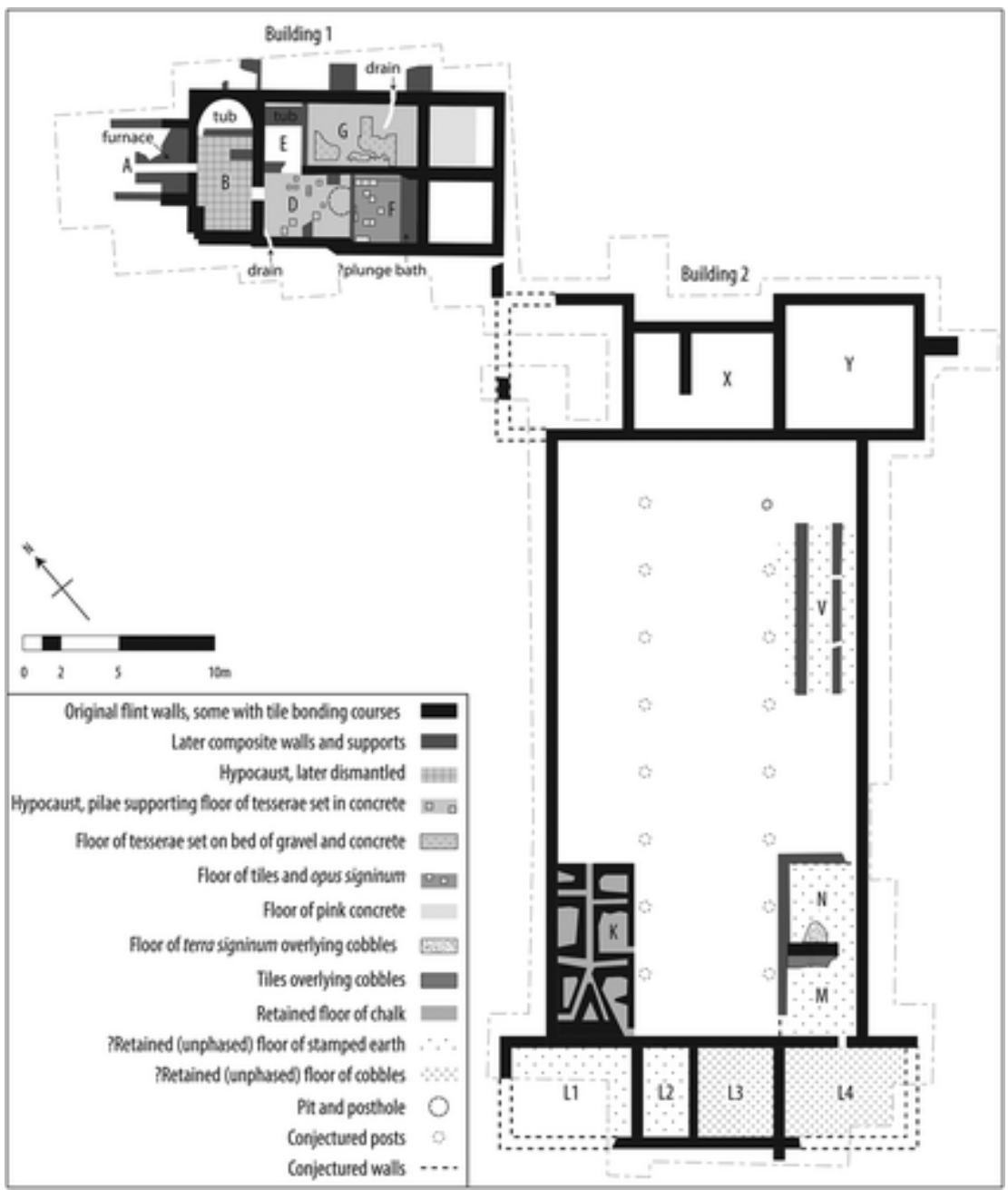

\section{Display full size}

Illus. 7. Watercolour painting of plaster fragments from Building 1 Room D (Liddell 1929Liddell, D.M. 1929. Report on the Excavation of a Roman Building at Lodge Farm, North Warnborough, Hants., Hampshire County Museums Headquarters Archives, unpublished manuscript[Google Scholar]). 


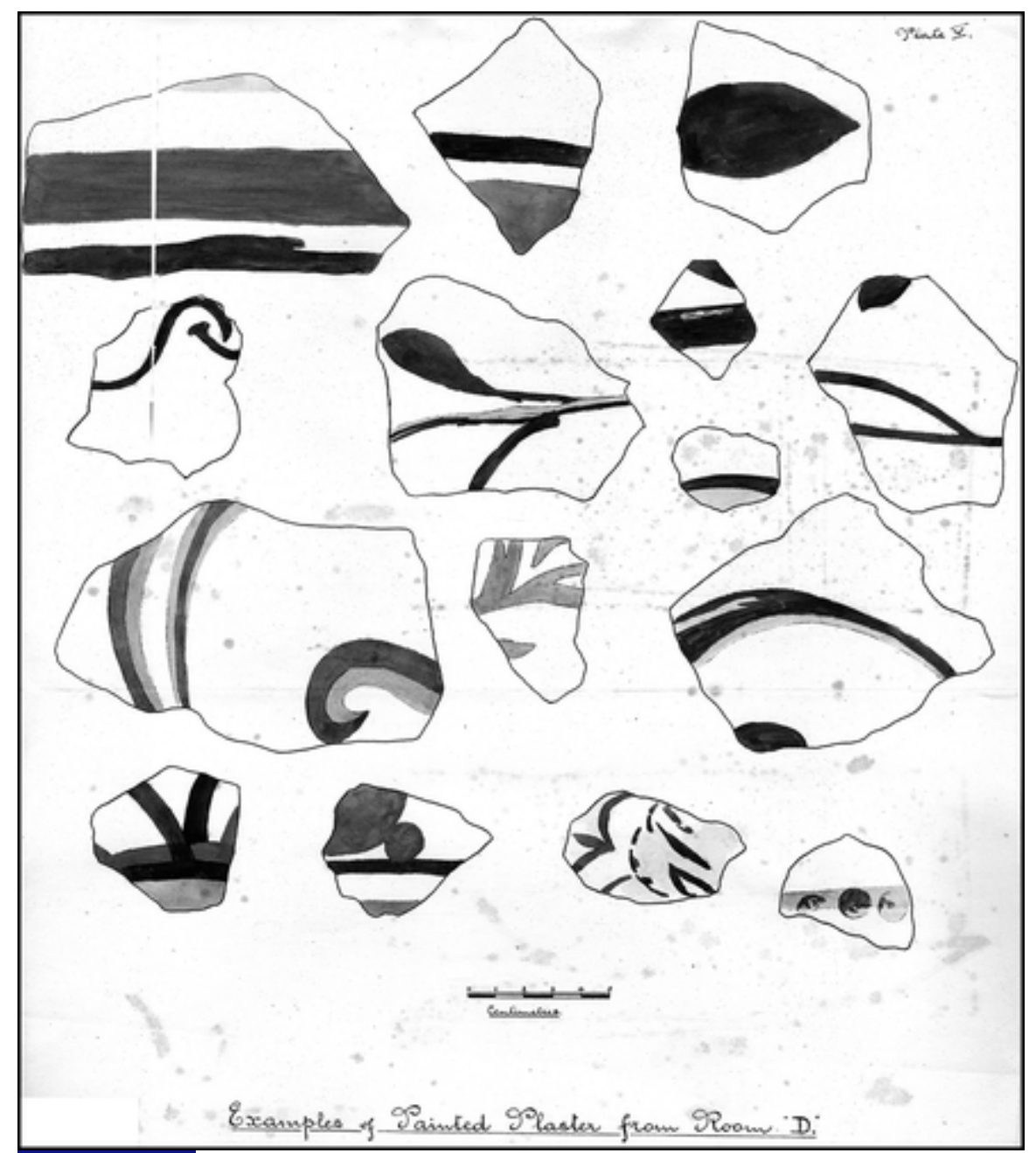

Display full size

Illus. 8. Phase 3 (after Liddell 1931Liddell, D.M. 1931. Notes on two excavations in Hampshire, Proc. of the Hampshire Field Club and Archaeol. Soc., 10, 224-236[Google Scholar], plate IV and Collingwood and Taylor 1931Collingwood, R. and Taylor, M.V. 1931. Roman Britain in 1930, J. of Roman Stud., 21, 215-250[Google Scholar], 243, fig. 24). Building 2 Room $K$ had plastered walls in white with a narrow red line and $O$ had dark rose-coloured walls; it is likely that these plaster fragments relate to this latest phase. Building 2 Room S contained a large quantity of wood ash, burning, as well as food remains, including oyster shells; Q contained a large midden of pottery, animal bones, and oyster shells; Room W contained a hearth. Postholes in the centre of the nave may be remains of supports for sagging roof beams towards the end of the life of the building-their locations are consistent with the aisle post reconstruction suggested in the illustrations here. 


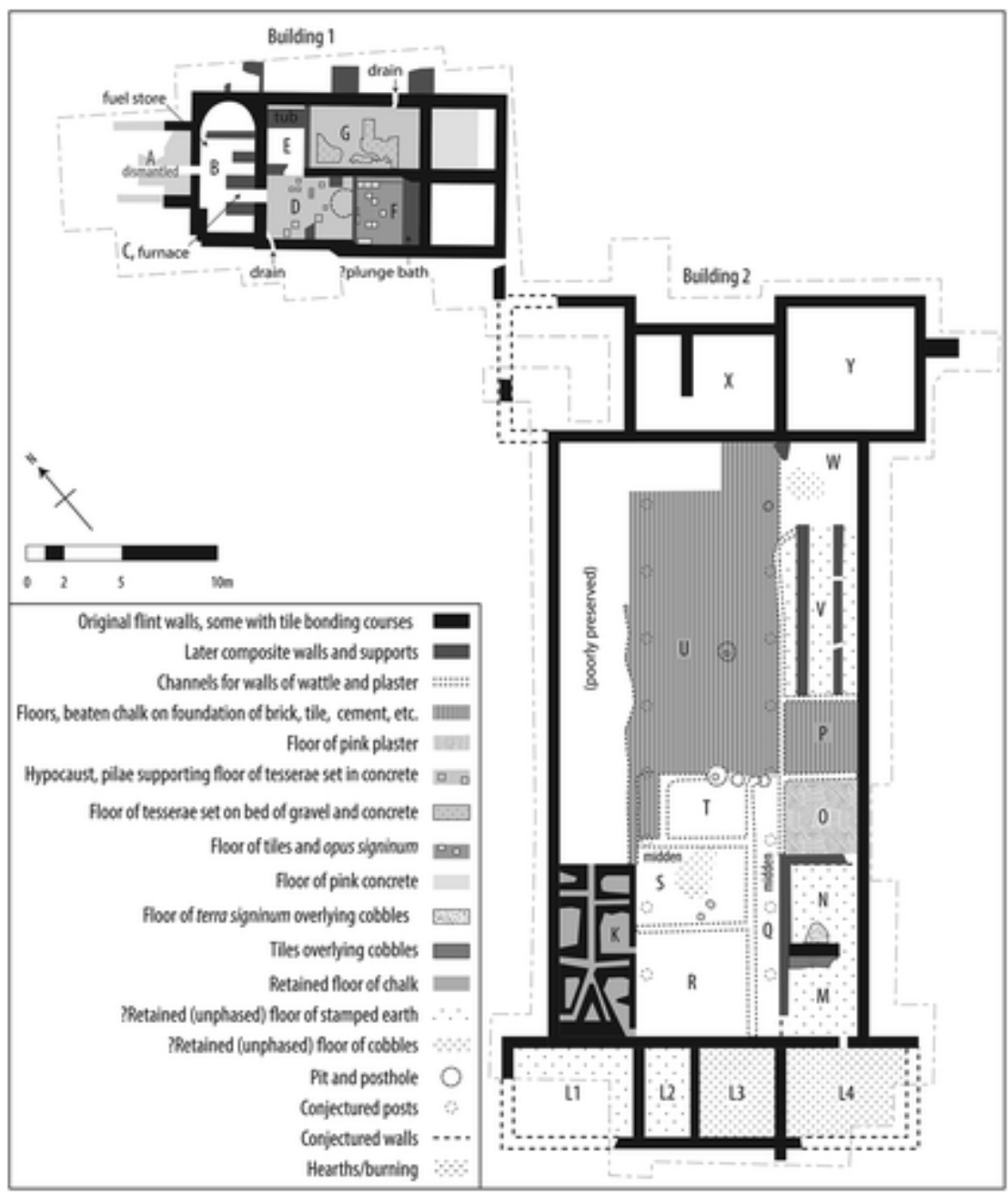

\section{Display full size}

Illus. 9. Bedrock geology between Calleva and North Warnborough showing known Roman-period roads and sites (from Allen et al. 2015Allen, M., Blick, N., Brindle, T. Evans, T., Fulford, M., Holbrook, N., Ri chards, J.D., and Smith, A. 2015 (updated 2016). The Rural Settlement of Roman Britain: an online resource, Archaeology Data Service,http://archaeologydataservice.ac.uk/archives/view/romangl/[Google Scholar]) and areas from which the aisled hall would have been visible (at 13 $\mathrm{m}$ height to a 1.8-m person; M3 motorway removed for processing). Scale 1:100,000. (Topographic data: Crown copyright/database right 2016. An Ordnance Survey/EDINA supplied service.) 


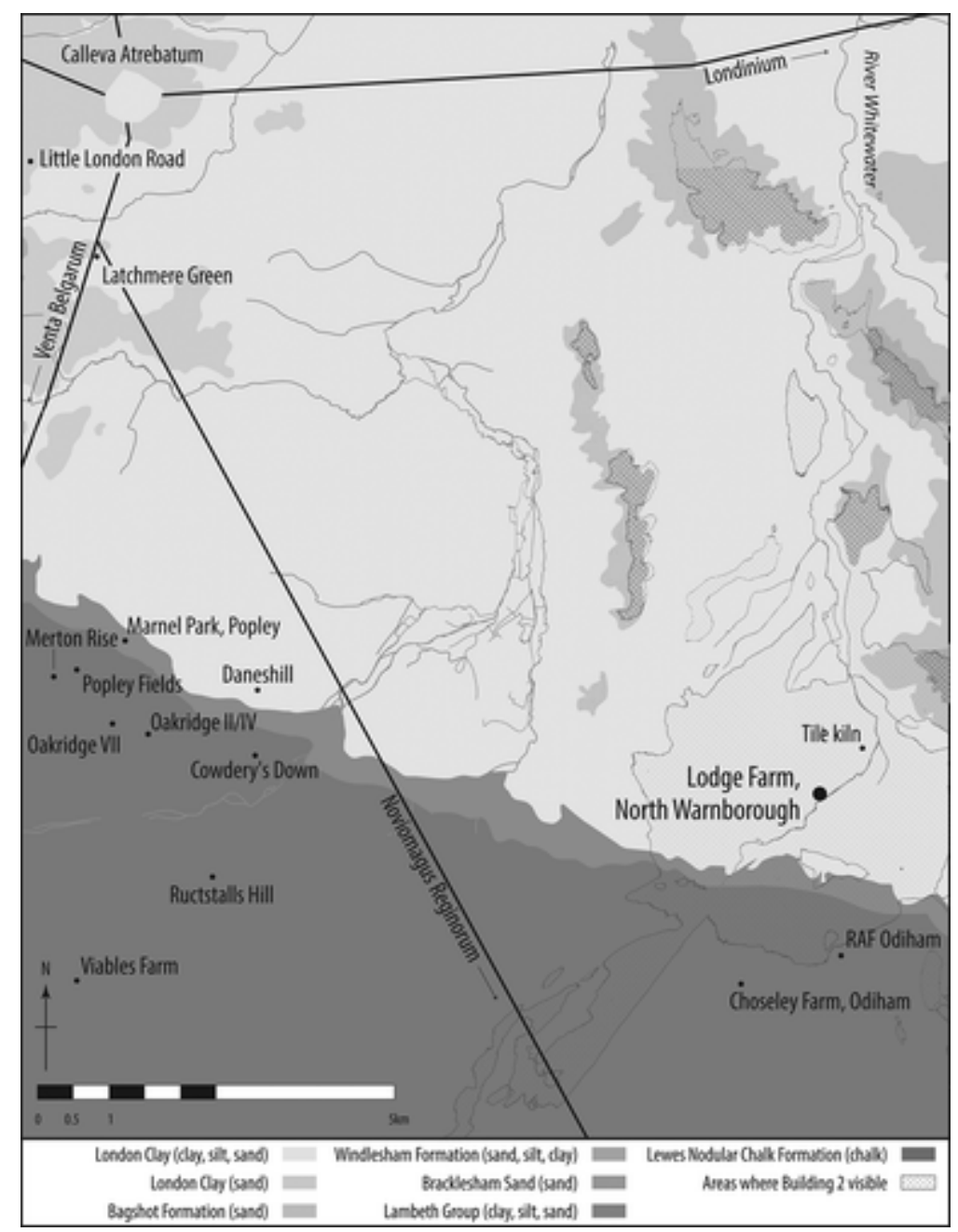

